Nevada

Environmental

Restoration

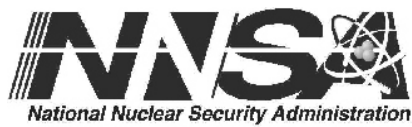

Project

Corrective Action Plan for Corrective Action Unit 168: Area 25 and 26 Contaminated Materials and Waste Dumps, Nevada Test Site, Nevada

Controlled Copy No.:

Revision: 1

December 2006

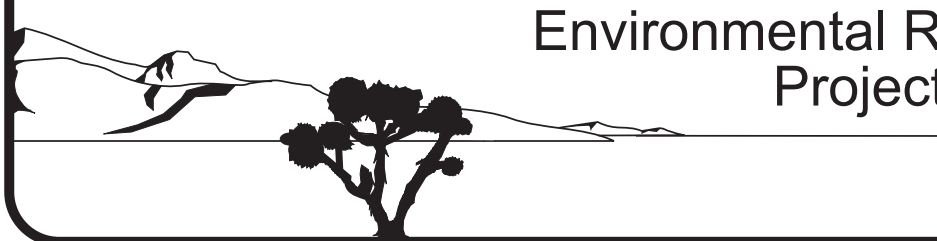




\title{
DISCLAIMER
}

Reference herein to any specific commercial product, process, or service by trade name, trademark, manufacturer, or otherwise, does not necessarily constitute or imply its endorsement, recommendation, or favoring by the U.S. Government or any agency thereof or its contractors or subcontractors.

This report has been reproduced directly from the best available copy.

Available for sale to the public from:

\author{
U.S. Department of Commerce \\ National Technical Information Service \\ 5285 Port Royal Road \\ Springfield, VA 22161-0002 \\ Telephone: (800) 553-6847 \\ Fax: (703) 605-6900 \\ E-mail: orders@ntis.gov \\ Online ordering: http://www.ntis.gov/ordering.htm
}

Available electronically at http://www.osti.gov/bridge.

Available for a processing fee to the U.S. Department of Energy and its contractors, in paper, from:

\author{
U.S. Department of Energy \\ Office of Scientific and Technical Information \\ P.O. Box 62 \\ Oak Ridge, TN 37831-0062 \\ Telephone: (865) 576-8401 \\ Fax: (865) 576-5728 \\ E-mail: reports@adonis.osti.gov
}




\title{
CORRECTIVE ACTION PLAN FOR CORRECTIVE ACTION UNIT 168: AREA 25 AND 26 CONTAMINATED MATERIALS AND WASTE DUMPS, NEVADA TEST SITE, NEVADA
}

\author{
U.S. Department of Energy \\ National Nuclear Security Administration \\ Nevada Site Office \\ Las Vegas, Nevada
}

Controlled Copy No.

Revision: 1

December 2006 
THIS PAGE INTENTIONALLY LEFT BLANK 


\section{CORRECTIVE ACTION PLAN FOR CORRECTIVE ACTION UNIT 168: AREA 25 AND 26 CONTAMINATED MATERIALS AND WASTE DUMPS, NEVADA TEST SITE, NEVADA}

John B. Jones

Acting Federal Project Director

Environmental Restoration Project 
THIS PAGE INTENTIONALLY LEFT BLANK 


\section{TABLE OF CONTENTS}

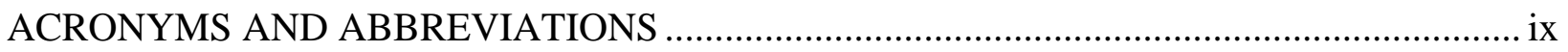

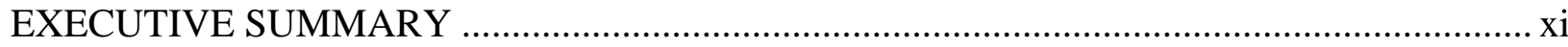

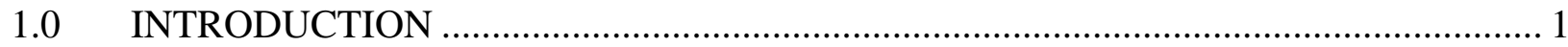

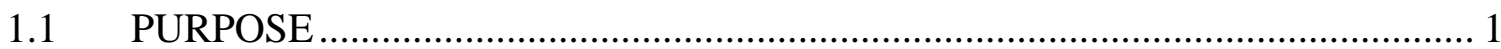

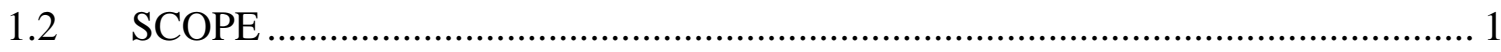

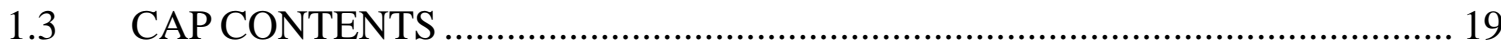

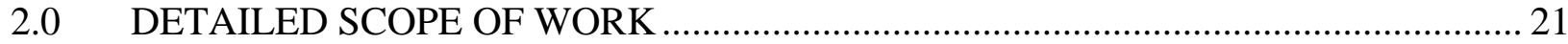

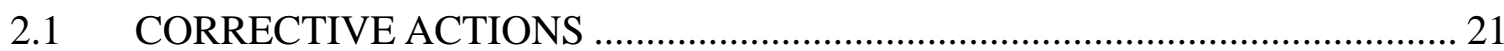

2.1.1 Alternative 1 - No Further Action............................................................. 21

2.1.2 Alternative 2 - Clean Closure ………………………............................. 21

2.1.2.1 CAS 25-16-01, Construction Waste Pile ……………………..... 21

2.1.2.2 CAS 25-23-13, ETL-Lab Radioactive Contamination ................ 22

2.1.2.3 CAS 25-23-18, Radioactive Material Storage ............................. 22

2.1.2.4 CAS 26-08-01, Waste Dump/Burn Pit......................................... 23

2.1.2.5 CAS 26-17-01, Pluto Waste Holding Area.................................. 24

2.1.2.6 CAS 26-19-02, Contaminated Waste Dump \#2.......................... 24

2.1.3 Alternative 3 - Close in Place with Administrative Controls .................... 24

2.1.3.1 CAS 25-16-03, MX Construction Landfill ................................ 24

2.1.3.2 CAS 25-23-02, Radioactive Storage RR Cars ............................ 25

2.1.3.3 CAS 25-99-16, USW G3 …………………………………... 25

2.2 CONSTRUCTION QUALITY ASSURANCE/QUALITY CONTROL ............... 25

2.2.1 Construction Field Sample Collection Activities ......................................... 25

2.2.2 Construction Laboratory/Analytical Data Quality Indicators.................... 26

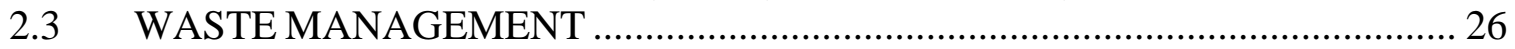

2.3.1 TPH Waste ............................................................................................ 26

2.3.2 Sanitary Waste/Construction Debris............................................................. 26

2.3.3 TSCA-Regulated Waste............................................................................ 26

2.3.4 Hazardous Waste ................................................................................. 26

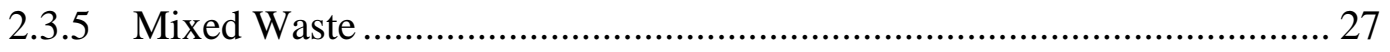

2.3.6 Asbestos-Containing Material .................................................................. 27

2.3.7 Low-Level Waste...................................................................................... 27

2.3.8 Decontamination Waste ........................................................................... 27

2.3.9 Personal Protective Equipment.................................................................. 27

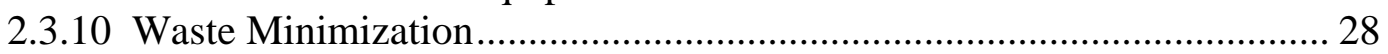

2.4 CONFIRMATION OF CORRECTIVE ACTIONS ............................................ 28

2.4.1 No Further Action Sites ........................................................................ 28

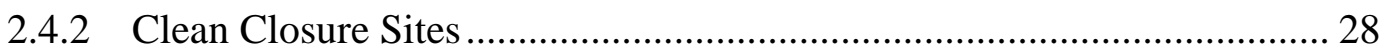

2.4.2.1 CAS 25-16-01, Construction Waste Pile ................................... 29

2.4.2.2 CAS 25-23-13, ETL-Lab Radioactive Contamination ............... 29

2.4.2.3 CAS 25-23-18, Radioactive Material Storage ............................. 29

2.4.2.4 CAS 26-08-01, Waste Dump/Burn Pit....................................... 29

2.4.2.5 CAS 26-17-01, Pluto Waste Holding Area................................. 30 


\section{TABLE OF CONTENTS (continued)}

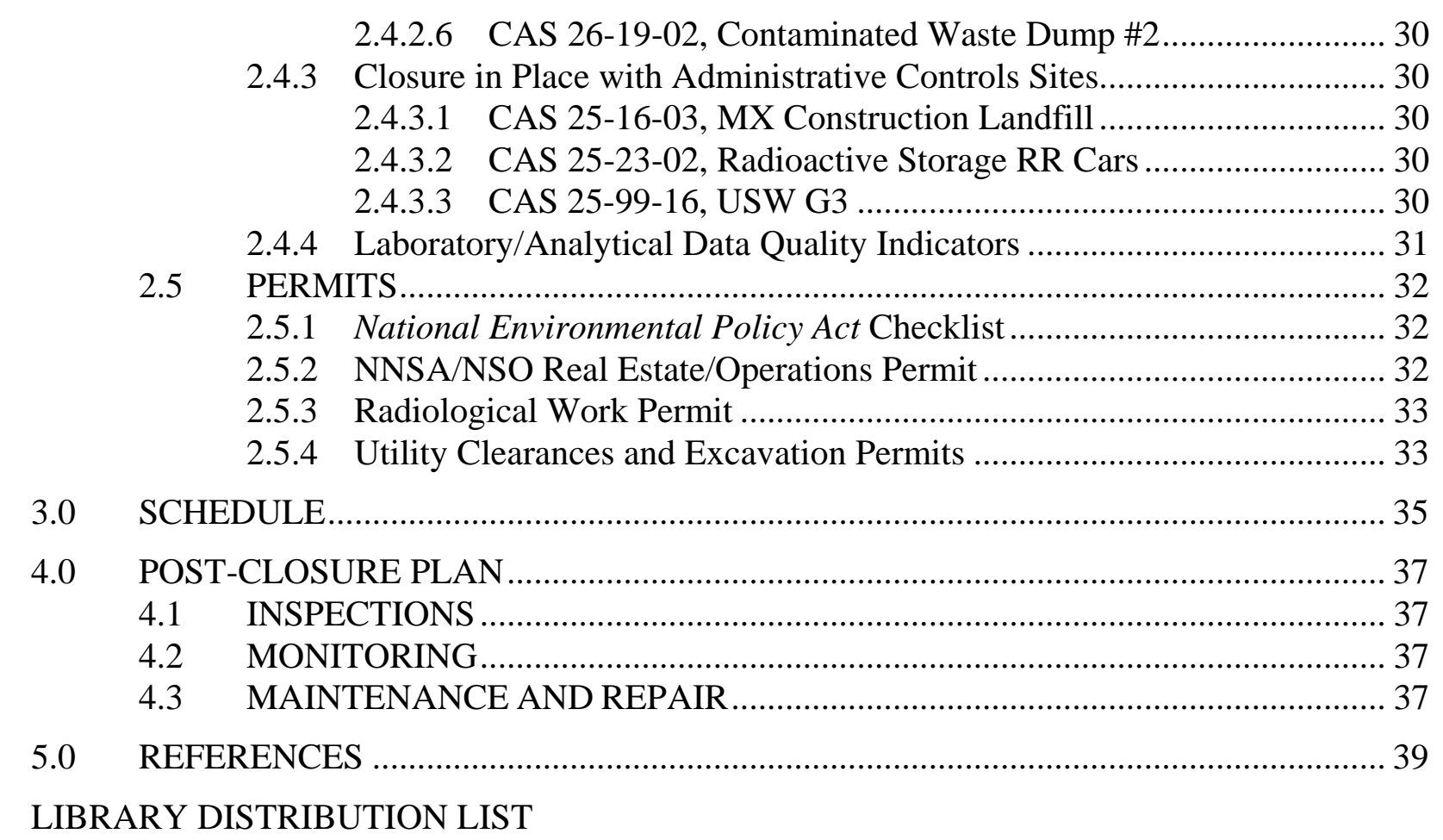

\section{LIST OF FIGURES}

Figure 1. LOCATION OF THE NTS AND CAU 168, AREA 25 AND 26 CONTAMinATED MATERIALS AND WASTE DUMPS

Figure 2. CAU 168 AREA 25 Corrective Action SiTES ........................................................ 3

Figure 3. CAU 168 AREA 26 Corrective Action SitES ......................................................... 4

Figure 4. CAS 25-16-01; Construction WASTE PiLE............................................................ 5

FIGURE 5. CAS 25-16-03; MX CONSTRUCTION LANDFILL ........................................................ 6

FIGURE 6. CAS 25-19-02; WASTE DISPOSAL SITE ............................................................ 7

FIGURE 7. CAS 25-23-02; RADIOACTIVE STORAGE RR CARS ................................................ 8

FIGURE 8. CAS 25-23-13; ETL-LAB RADIOACTIVE CONTAMINATION ........................................ 9

Figure 9. CAS 25-23-18; RADIOACTIVE MATERIAL STORAGE ............................................... 10

FIGURE 10. CAS 25-34-01; NRDS CONTAMINATED BUNKER .................................................. 11

FIGURE 11. CAS 25-34-02; NRDS CONTAMINATED BUNKER ................................................. 12

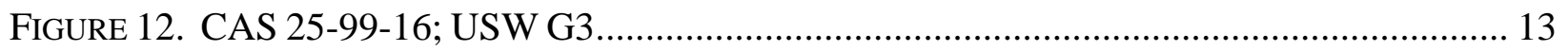

FIGURE 13. CAS 26-08-01; WASTE DUMP/BURN PIT ........................................................... 14

Figure 14. CAS 26-17-01; Pluto WASte Holding AREA ..................................................... 15

FIgURE 15. CAS 26-19-02; CONTAMINATED WASTE DUMP \#2 ................................................ 16 


\section{TABLE OF CONTENTS (continued)}

\section{LIST OF TABLES}

Table 1. CAU 168 Closure Activities

TABle 2. ClEANUP CRITERIA FOR CAU 168

TABLE 3. ETL-LAB RADiOACTIVE CONTAMINATION, EQUiPMENT TO BE REMOVED

\section{APPENDICES}

APPENDIX A.1 - ENGINEERING SPECIFICATIONS AND DRAWINGS

APPENDIX A.2 - SAMPLING AND ANALYSIS PLAN

APPENDIX A.3 - PROJECT ORGANIZATION 
CAP - CAU 168

Section: Table of Contents

Revision: 1

Date: December 2006

THIS PAGE INTENTIONALLY LEFT BLANK 


\section{ACRONYMS AND ABBREVIATIONS}

ACM asbestos-containing material

BN Bechtel Nevada

CA contamination area

CADD Corrective Action Decision Document

CAIP Corrective Action Investigation Plan

CAP Corrective Action Plan

CAS Corrective Action Site

CAU Corrective Action Unit

COC contaminant of concern

CR Closure Report

Cs-137 cesium-137

DOE U.S. Department of Energy

DOE/NV U.S. Department of Energy, Nevada Operations Office

DQI data quality indicators

DQO data quality objective

E-MAD Engine Maintenance, Assembly, and Disassembly

EPA U.S. Environmental Protection Agency

ETL Engine Test Laboratory

FFACO Federal Facility Agreement and Consent Order

$\mathrm{ft} \quad$ foot (feet)

HEPA high-efficiency particulate air

HW hazardous waste

ISOCS In-Situ Object Counting System

LLW low-level waste

m meter(s)

$\mathrm{m}^{3} \quad$ cubic meter(s)

$\mathrm{mg} / \mathrm{kg} \quad$ milligram(s) per kilogram

MW mixed waste

MX Missile Experiment

NAC Nevada Administrative Code

NDEP Nevada Division of Environmental Protection 


\section{ACRONYMS AND ABBREVIATIONS (continued)}

\begin{tabular}{|c|c|}
\hline NEPA & National Environmental Policy Act \\
\hline NNSA/NSO & $\begin{array}{l}\text { U.S. Department of Energy, National Nuclear Security Administration Nevada } \\
\text { Site Office }\end{array}$ \\
\hline NNSA/NV & $\begin{array}{l}\text { U.S. Department of Energy, National Nuclear Security Administration Nevada } \\
\text { Operations Office }\end{array}$ \\
\hline NRDS & Nuclear Rocket Development Station \\
\hline NSTec & National Security Technologies, LLC \\
\hline NTS & Nevada Test Site \\
\hline NV/YMP & Nevada/Yucca Mountain Project \\
\hline OI & Operating Instruction \\
\hline PCBs & polychlorinated biphenyls \\
\hline $\mathrm{pCi} / \mathrm{g}$ & picoCuries per gram \\
\hline PPE & personal protective equipment \\
\hline $\mathrm{QA} / \mathrm{QC}$ & quality assurance/quality control \\
\hline REOP & Real Estate/Operations Permit \\
\hline RMSF & Radioactive Material Storage Facility \\
\hline RPD & relative percent difference \\
\hline $\mathrm{RR}$ & railroad \\
\hline RWP & Radiological Work Permit \\
\hline Sr-90 & strontium-90 \\
\hline $\mathrm{TPH}$ & total petroleum hydrocarbons \\
\hline TSCA & Toxic Substances Control Act \\
\hline TSD & treatment, storage, and disposal \\
\hline $\mathrm{U}-234$ & uranium-234 \\
\hline U-235 & uranium-235 \\
\hline UR & use restriction \\
\hline USW & Underground Southern Nevada Well \\
\hline $\mathrm{yd}^{3}$ & cubic yard(s) \\
\hline
\end{tabular}


Corrective Action Unit (CAU) 168 is identified in the Federal Facility Agreement and Consent Order of 1996 as Area 25 and 26 Contaminated Materials and Waste Dumps. CAU 168 consists of twelve Corrective Action Sites (CASs) in Areas 25 and 26 of the Nevada Test Site, which is approximately 105 kilometers (65 miles) northwest of Las Vegas, Nevada. The CASs contain surface and subsurface debris, impacted soil, and contaminated materials.

Site characterization activities were conducted in 2002, and the results are presented in the Corrective Action Decision Document (CADD) for CAU 168 (U.S. Department of Energy, National Nuclear Security Administration Nevada Site Office [NNSA/NSO], 2006). Site characterization results indicated that soil at several sites exceeded the clean-up criteria for total petroleum hydrocarbons (TPH), polychlorinated biphenyls (PCBs), and radionuclides.

The Nevada Division of Environmental Protection approved the proposed corrective actions specified in the CADD (NNSA/NSO, 2006). The approved corrective actions include no further action, clean closure, and closure in place with administrative controls.

No further action will be implemented at the following CASs, as no contaminants of concern were identified:

- CAS 25-19-02, Waste Disposal Site

- CAS 25-34-01, NRDS Contaminated Bunker

- CAS 25-34-02, NRDS Contaminated Bunker

Clean closure will be implemented at the following CASs:

- CAS 25-16-01, Construction Waste Pile: This site contains subsurface construction debris in two target area locations. Approximately 77 cubic meters $\left(\mathrm{m}^{3}\right)\left(100\right.$ cubic yards $\left.\left[\mathrm{yd}^{3}\right]\right)$ of surface debris present in a small mound in Target Area 1 will be removed and properly disposed. Approximately $1,617 \mathrm{~m}^{3}\left(2,100 \mathrm{yd}^{3}\right)$ of subsurface construction debris in Target Area 1 and approximately $3.85 \mathrm{~m}^{3}\left(5 \mathrm{yd}^{3}\right)$ of subsurface construction debris in Target Area 2 will be excavated and properly disposed. The excavations will be backfilled with clean fill. In addition, approximately $1.5 \mathrm{~m}^{3}\left(2 \mathrm{yd}^{3}\right)$ of TPH-impacted soil will be excavated from Target Area 1 and properly disposed. Prior to backfilling, the TPH-impacted soil excavation will be sampled to verify the closure objectives have been met.

- CAS 25-23-13, ETL-Lab Radioactive Contamination: This site consists of the following radiologically impacted equipment: posted fume hood, oven, paddle mixer, non-posted fume hood, twin shell dry blender, and rooftop high-efficiency particulate air units. The contaminated equipment, ventilation system, and associated duct work will be removed and disposed. The remaining structure will be decontaminated, if necessary, and a radiological survey will be performed to verify removal of contamination.

- CAS 25-23-18, Radioactive Material Storage: This site is impacted with TPH, PCBs, uranium-234, uranium-235, strontium-90, and cesium-137. A total volume of approximately $7 \mathrm{~m}^{3}\left(9 \mathrm{yd}^{3}\right)$ of soil will be excavated and disposed. Samples will be collected from the excavations to verify the closure objectives have been met prior to backfilling. Steel storage casks, discarded equipment/materials including solid lead items located between the " $M$ " and "N" railroad (RR) spurs, and other miscellaneous surface debris including dicalite bags and a 
transportainer will be removed and disposed. The equipment/materials consists of sanitary waste and low-level waste and will be segregated prior to disposal. A radiological survey will be performed in the area after removal of these items. If possible, the footprint of the inner fenced area will be reduced depending on radiological survey results.

- CAS 26-08-01, Waste Dump/Burn Pit: This site contains surface construction debris, asbestos-containing material (ACM), and approximately $0.7 \mathrm{~m}^{3}\left(1 \mathrm{yd}^{3}\right)$ of TPH-impacted soil. The TPH-impacted soil will be excavated and disposed. Prior to backfilling, the excavation will be sampled to verify the closure objectives have been met. Approximately $847 \mathrm{~m}^{3}\left(1,100 \mathrm{yd}^{3}\right)$ of surface construction debris and ACM will be removed, segregated, and properly disposed.

- CAS 26-17-01, Pluto Waste Holding Area: The site contains approximately $1.5 \mathrm{~m}^{3}\left(2 \mathrm{yd}^{3}\right)$ of TPH-impacted soil and approximately $2.1 \mathrm{~m}^{3}\left(3 \mathrm{yd}^{3}\right)$ of PCB-impacted soil. The impacted soil will be excavated and disposed. Prior to backfilling, the excavations will be sampled to verify the closure objectives have been met. In addition, the outlet of a drainage pipe will be sealed with grout.

- CAS 26-19-02, Contaminated Waste Dump \#2: This site contains buried debris in a concrete retention structure. The debris includes radiologically contaminated metallic debris, solid lead items, and approximately $460 \mathrm{~m}^{3}\left(600 \mathrm{yd}^{3}\right)$ of construction debris. The debris will be excavated, segregated from the soil, and properly disposed. Although no COCs were identified in the soil during site characterization (NNSA/NSO, 2006), if contamination is identified during closure activities, the soil will be properly disposed. The remaining concrete retention structure will be decontaminated, if necessary, and a radiological survey will be performed to verify removal of contamination. The excavation will be backfilled with clean soil. Clean overburden soil may be used as backfill material.

Closure in place with administrative controls will be implemented at the following CASs:

- CAS 25-16-03, MX Construction Landfill: This site consists of two subsurface disposal cells containing buried construction debris. No COCs were identified at this site during site characterization (NNSA/NSO, 2006). Approximately $7.7 \mathrm{~m}^{3}\left(10 \mathrm{yd}^{3}\right)$ of metal conduit will be removed from the surface and disposed as a best management practice. An engineered soil cover will be installed with a minimum thickness of 0.6 meters ( 2 feet) at a 2 to 4 percent slope. Surface runoff controls will be put in place. Use restriction (UR) warning signs will be posted, and a three-strand wire fence will be installed.

- CAS 25-23-02, Radioactive Storage RR Cars: This site contains nineteen RR cars that are located at the Radioactive Material Storage Facility. The RR cars will be closed in place with administrative controls. UR warning signs will be posted.

- CAS 25-99-16, USW G3: This site contains a radiological source that was entombed in a subsurface borehole/well. UR warning signs will be posted. 


\subsection{INTRODUCTION}

Corrective Action Unit (CAU) 168 is listed in the Federal Facility Agreement and Consent Order (FFACO) of 1996 as Area 25 and 26 Contaminated Materials and Waste Dumps and consists of twelve Corrective Action Sites (CASs) located in Areas 25 and 26 of the Nevada Test Site (NTS) (Figure 1). The NTS is located approximately 105 kilometers (65 miles) northwest of Las Vegas, Nevada. The twelve CASs are shown in Figure 2 through Figure 15 and include:

- CAS 25-16-01, Construction Waste Pile

- CAS 25-16-03, MX Construction Landfill

- CAS 25-19-02, Waste Disposal Site

- CAS 25-23-02, Radioactive Storage RR Cars

- CAS 25-23-13, ETL-Lab Radioactive Contamination

- CAS 25-23-18, Radioactive Material Storage

- CAS 25-34-01, NRDS Contaminated Bunker

- CAS 25-34-02, NRDS Contaminated Bunker

- CAS 25-99-16, USW G3

- CAS 26-08-01, Waste Dump/Burn Pit

- CAS 26-17-01, Pluto Waste Holding Area

- CAS 26-19-02, Contaminated Waste Dump \#2

\subsection{PURPOSE}

This Corrective Action Plan (CAP) presents the detailed scope of work required to accomplish the closure alternatives specified in the Corrective Action Decision Document (CADD) for CAU 168 (U.S. Department of Energy, National Nuclear Security Administration Nevada Site Office [NNSA/NSO], 2006). Information on the site history and the plan to characterize the CAU are located in the Corrective Action Investigation Plan (CAIP) (U.S. Department of Energy, National Nuclear Security Administration Nevada Operations Office [NNSA/NV], 2001). Site characterization activities were performed in 2002, and the results are reported in Appendix A of the CADD (NNSA/NSO, 2006). The CADD also proposes the appropriate corrective actions for each CAS.

\subsection{SCOPE}

The approved closure activities for CAU 168 include removal of debris and excavation of impacted soil. Table 1 presents a summary of CAS-specific closure activities and contaminants of concern (COCs). Specific details of the corrective actions to be performed at each CAS are presented in Section 2.0 of this report. 


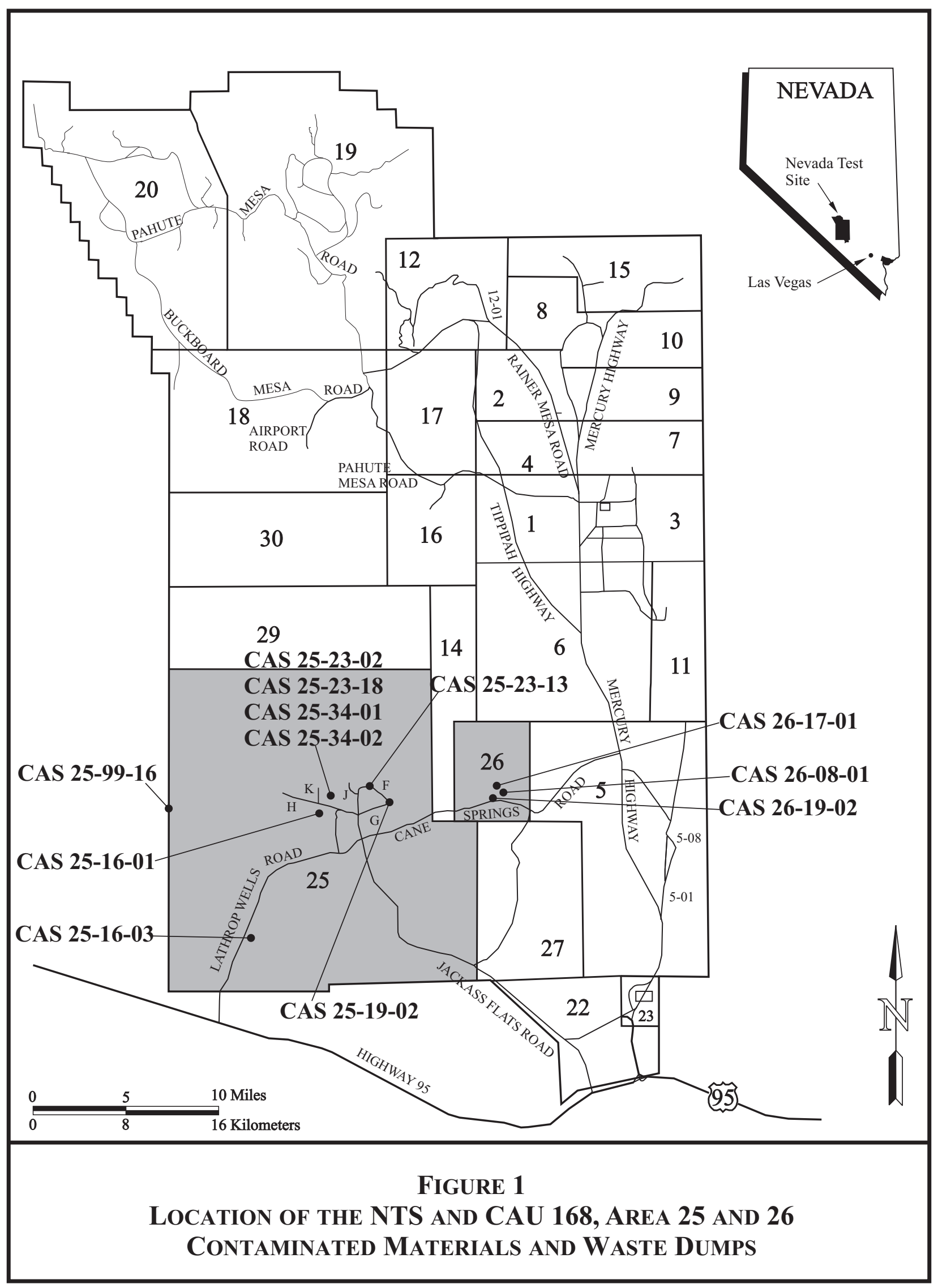




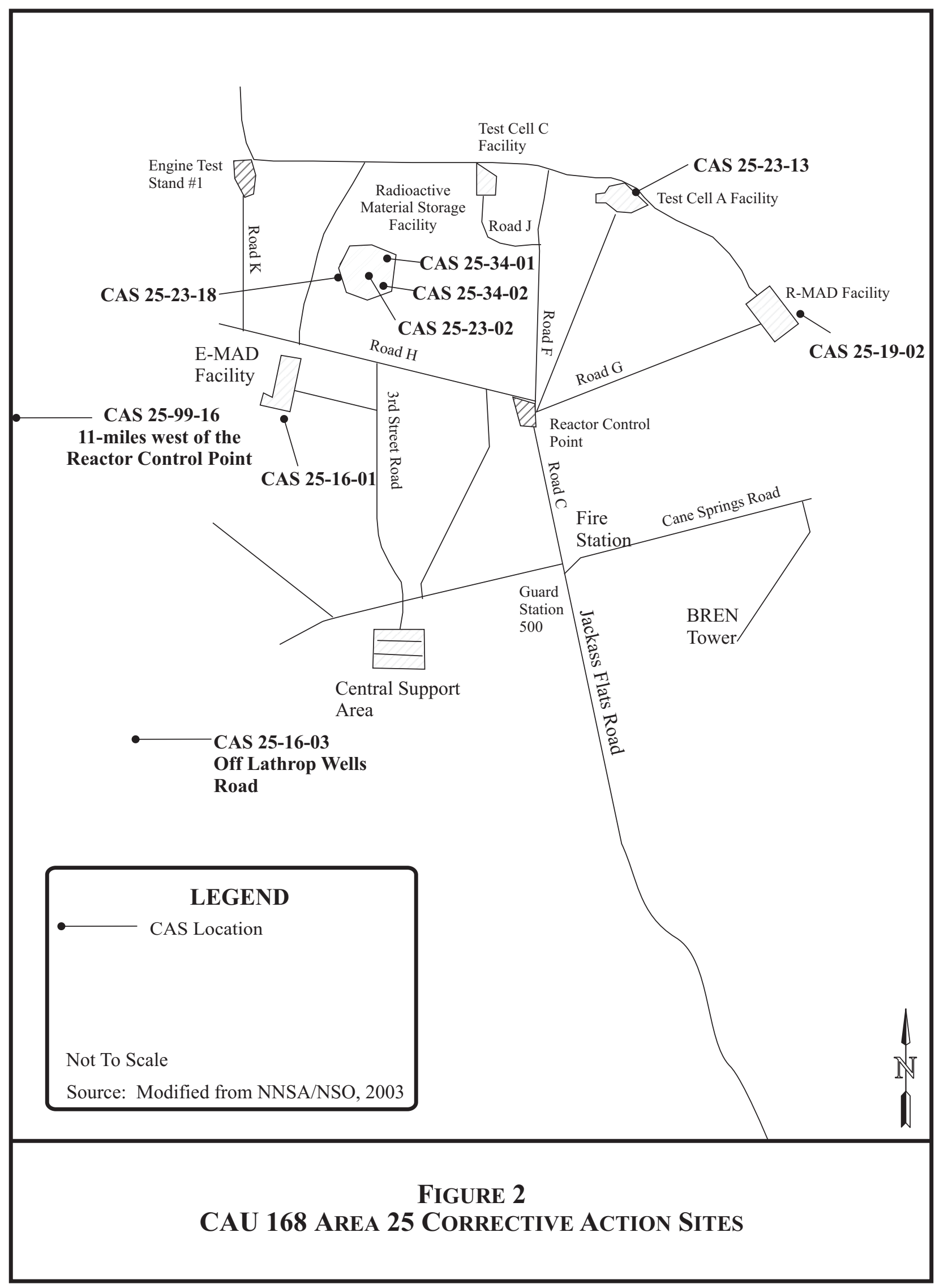




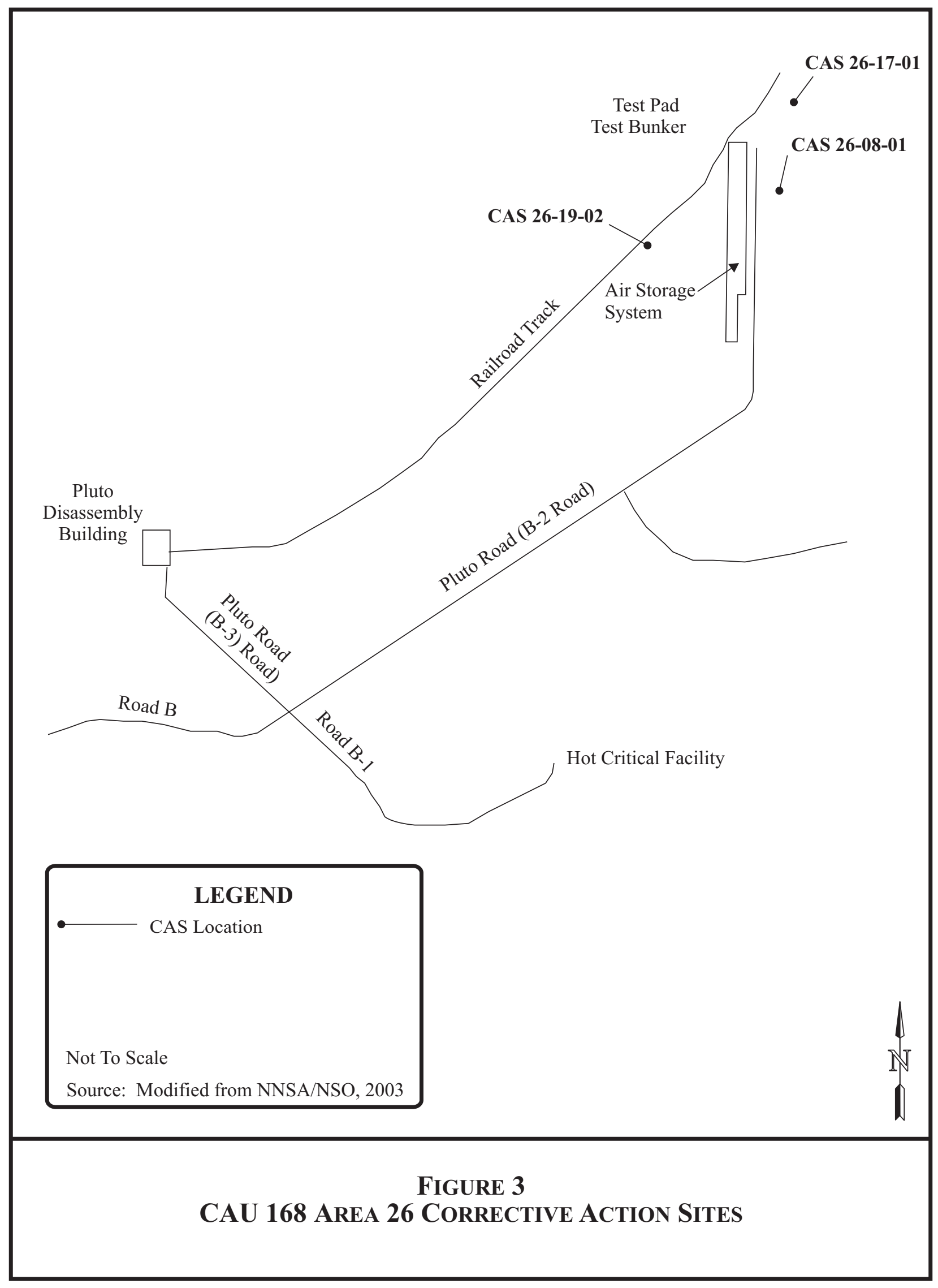




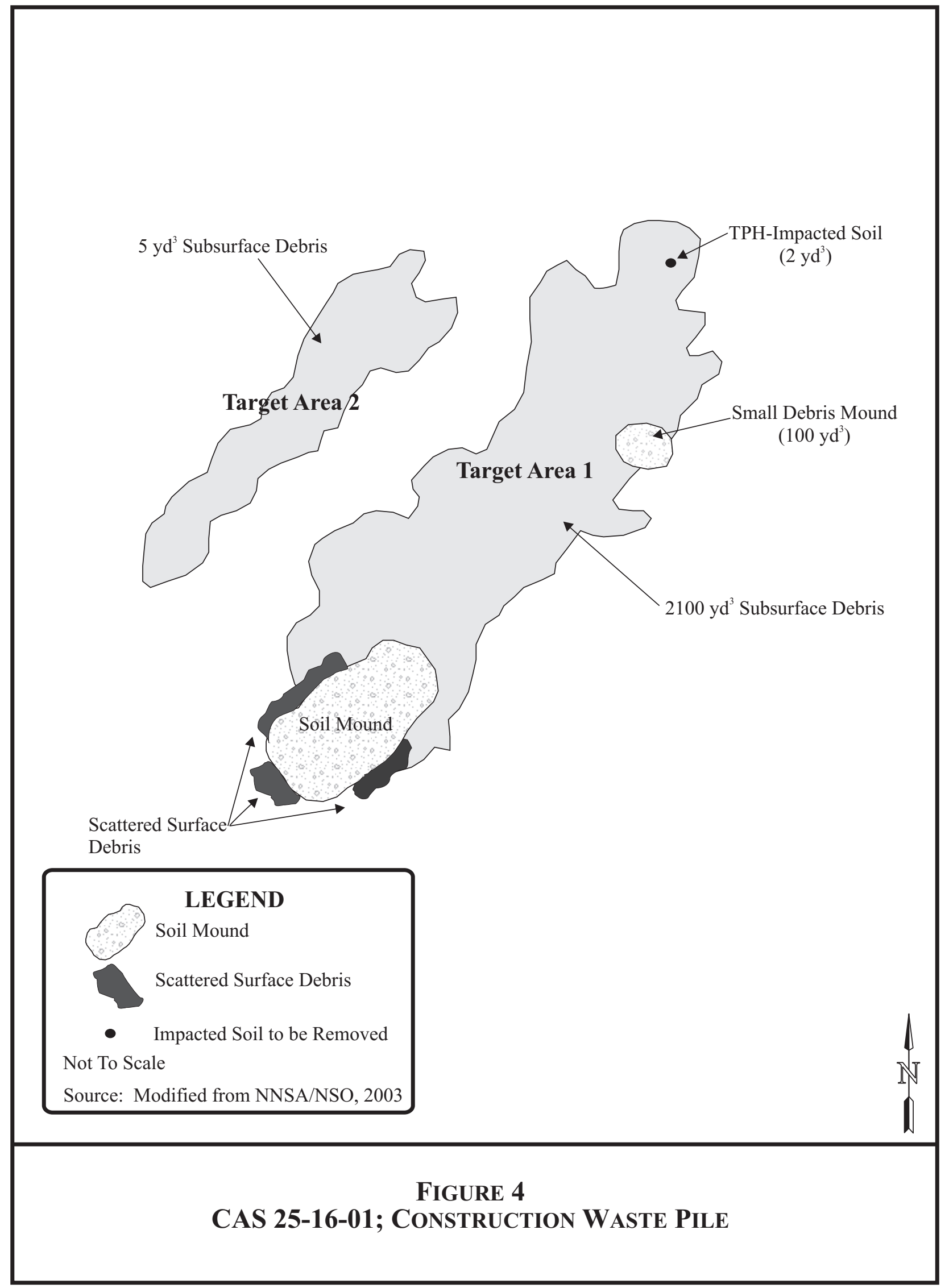




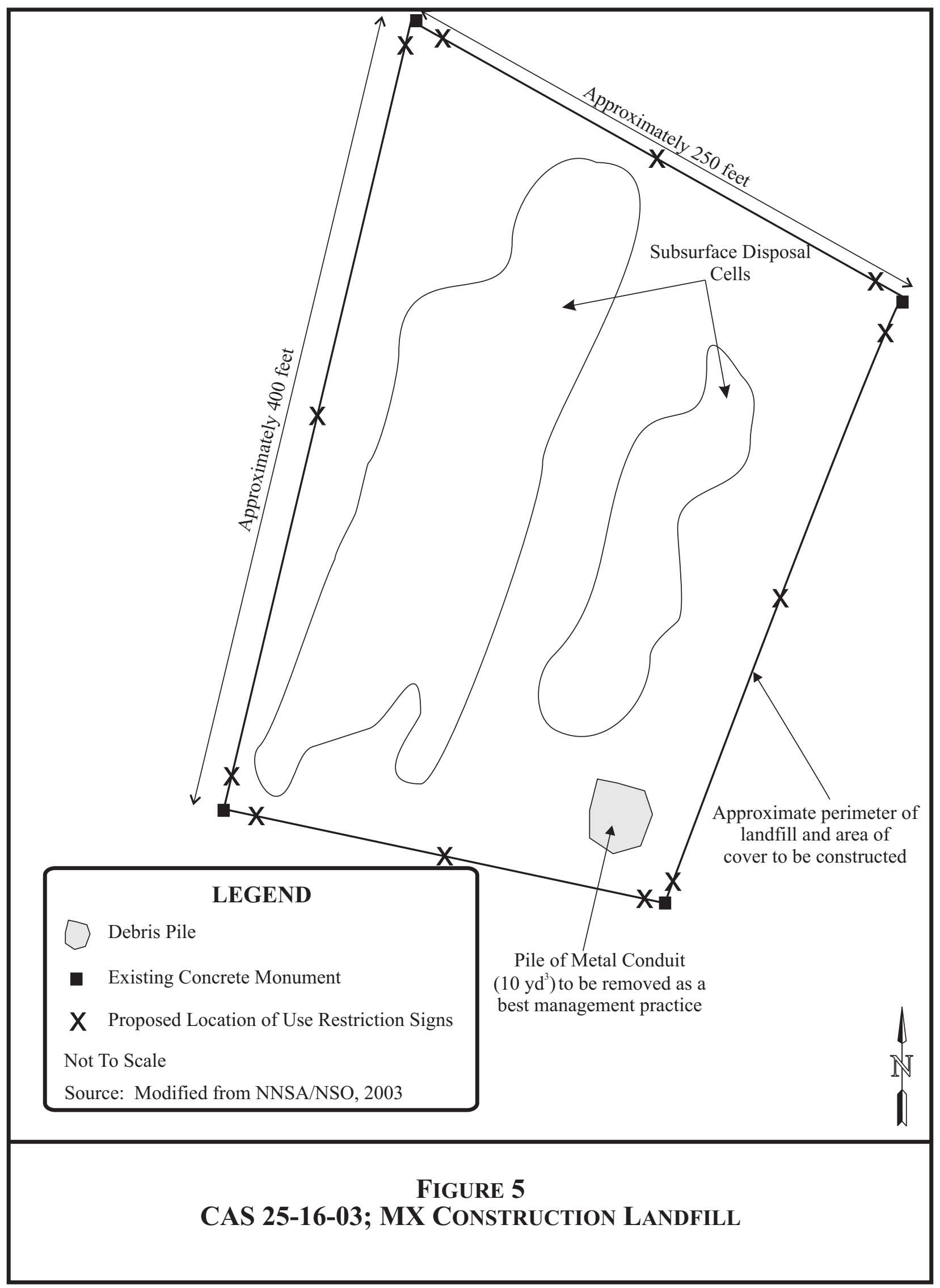




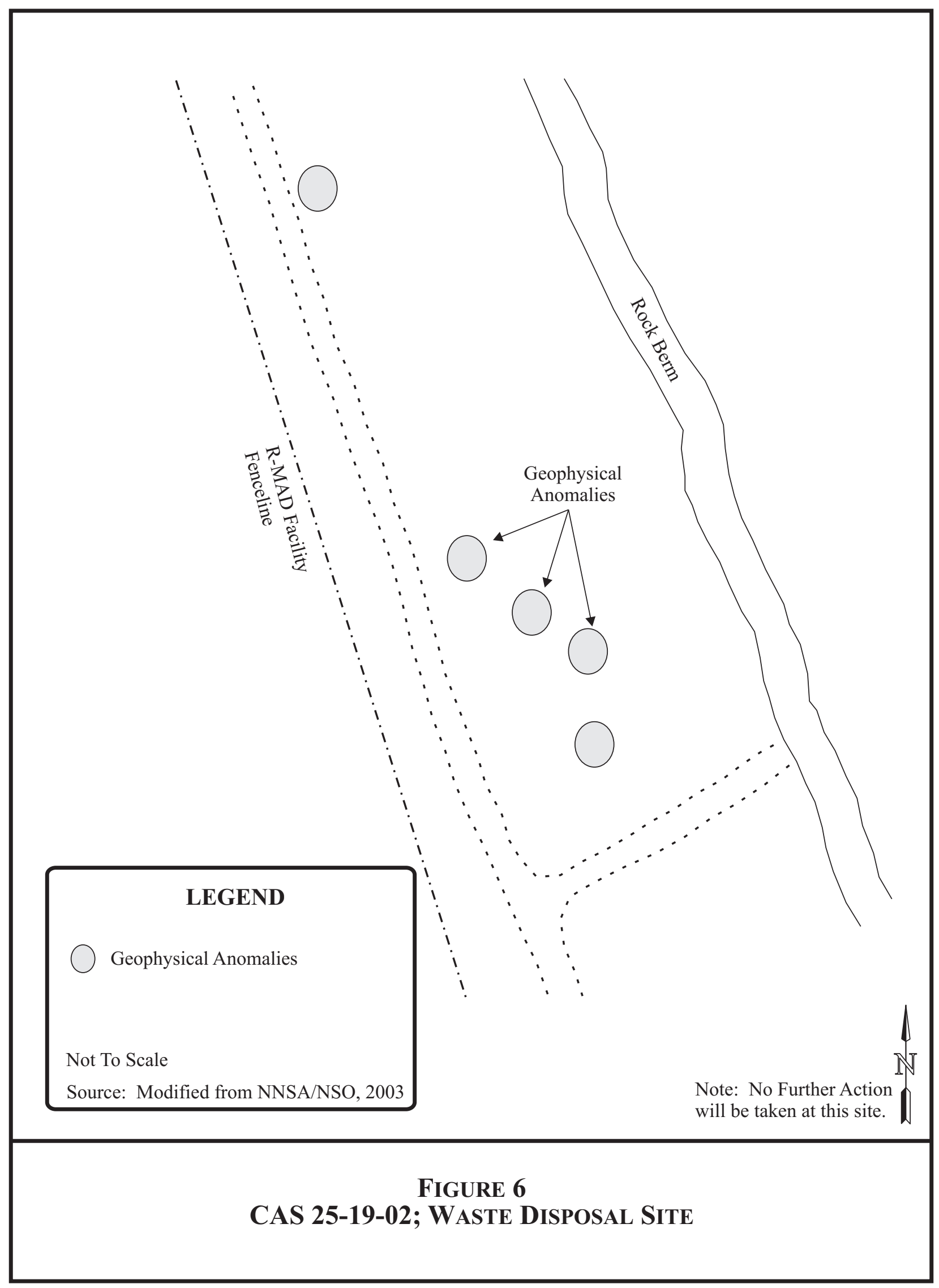




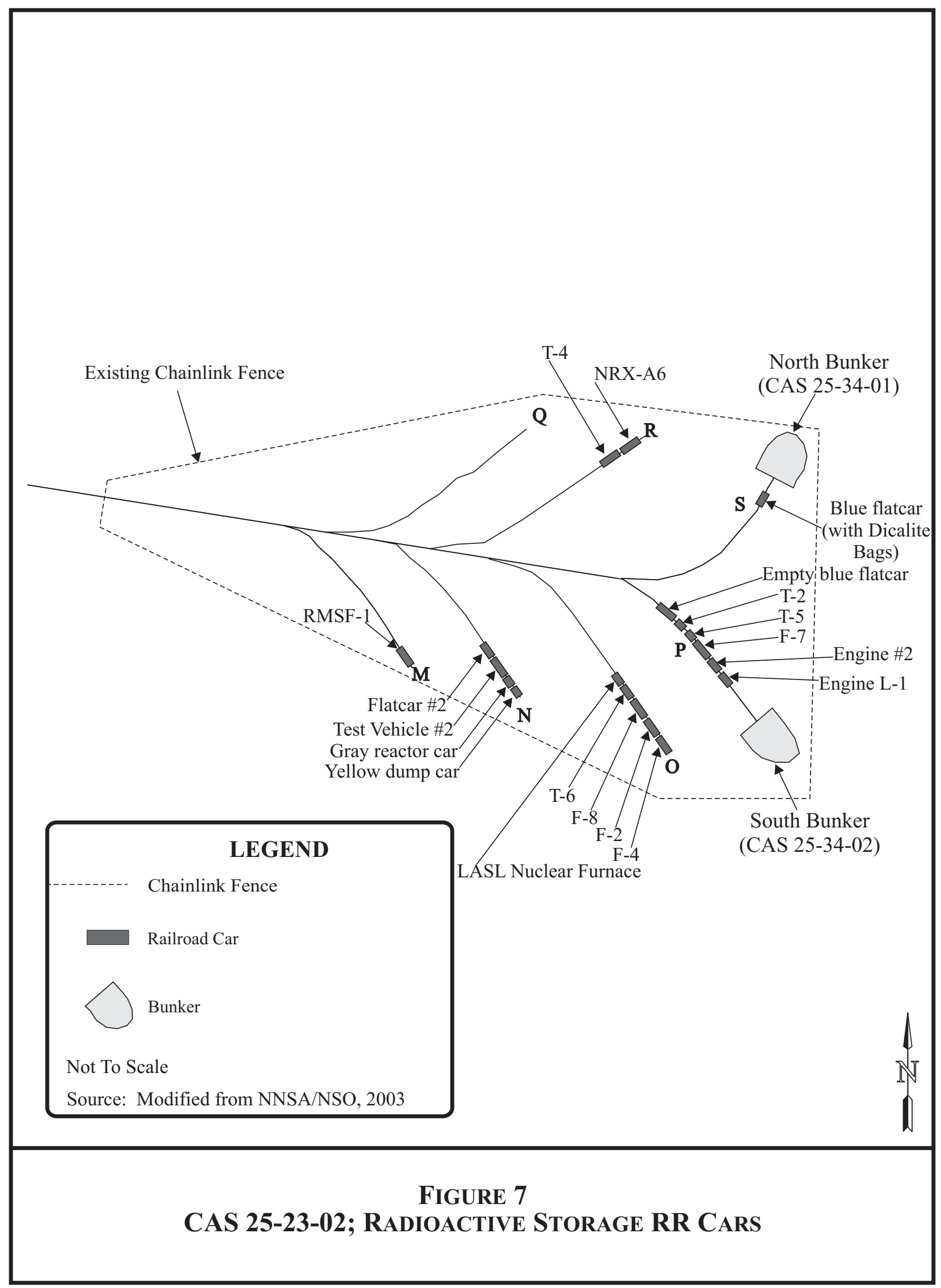




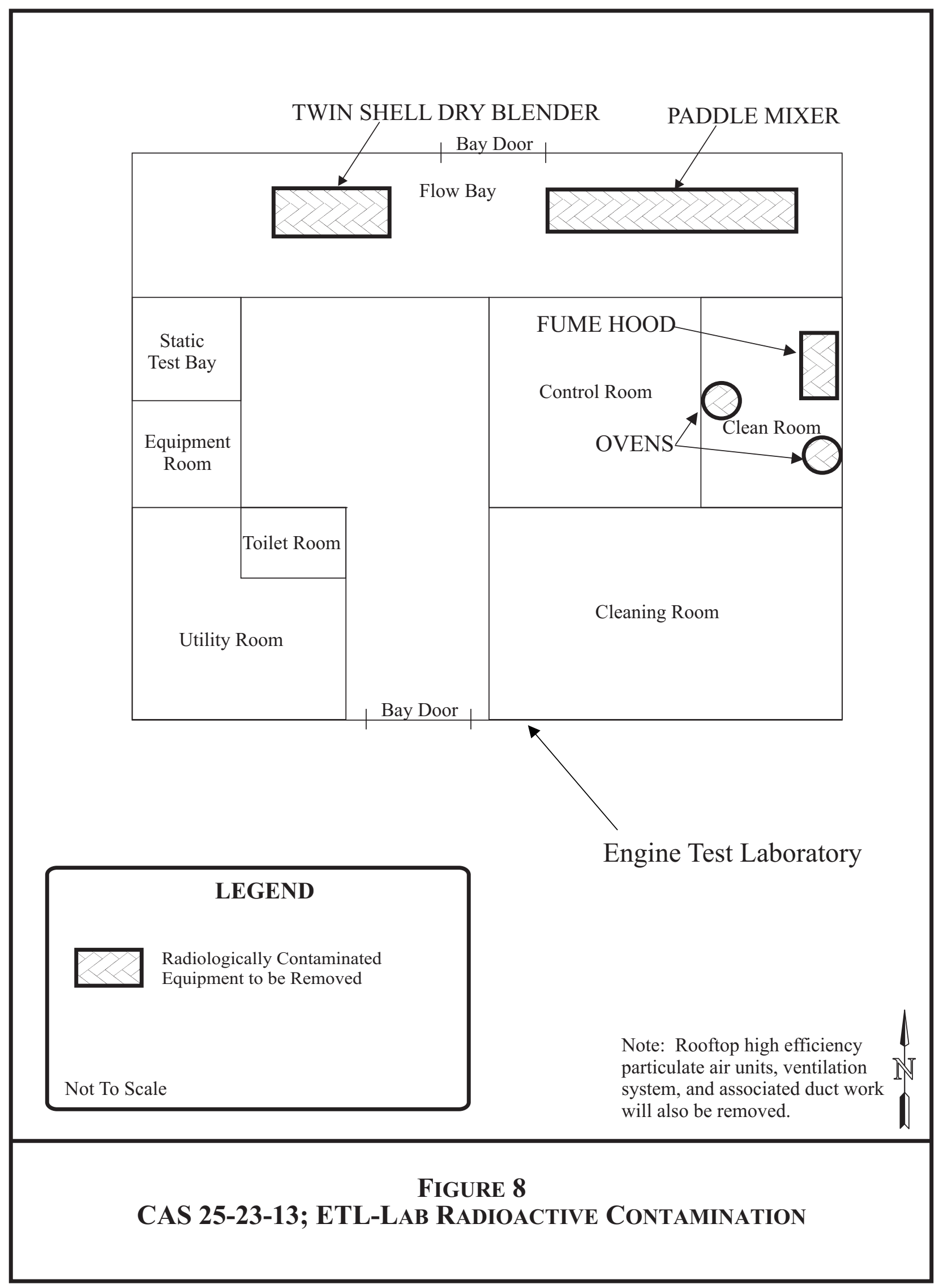




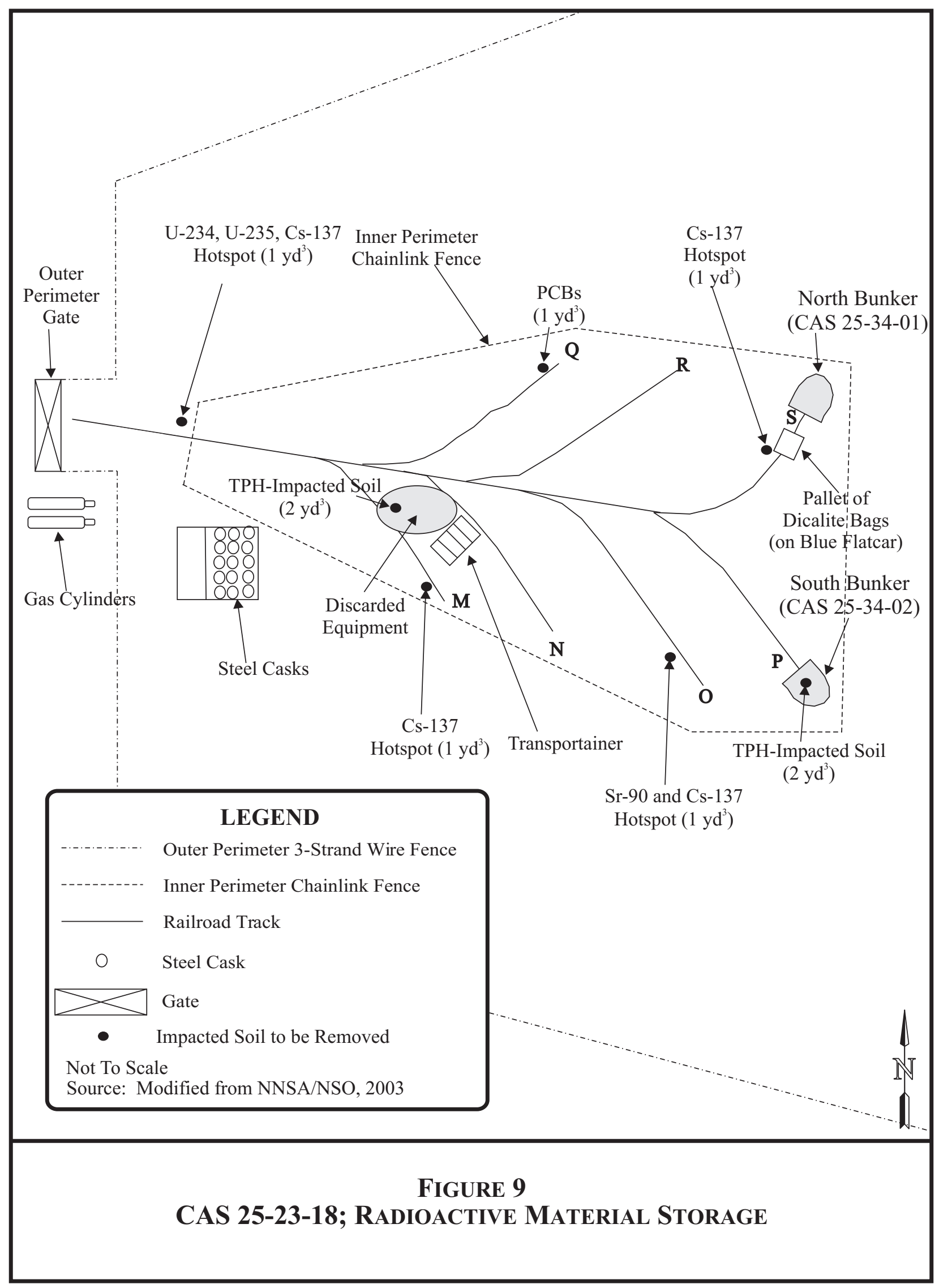




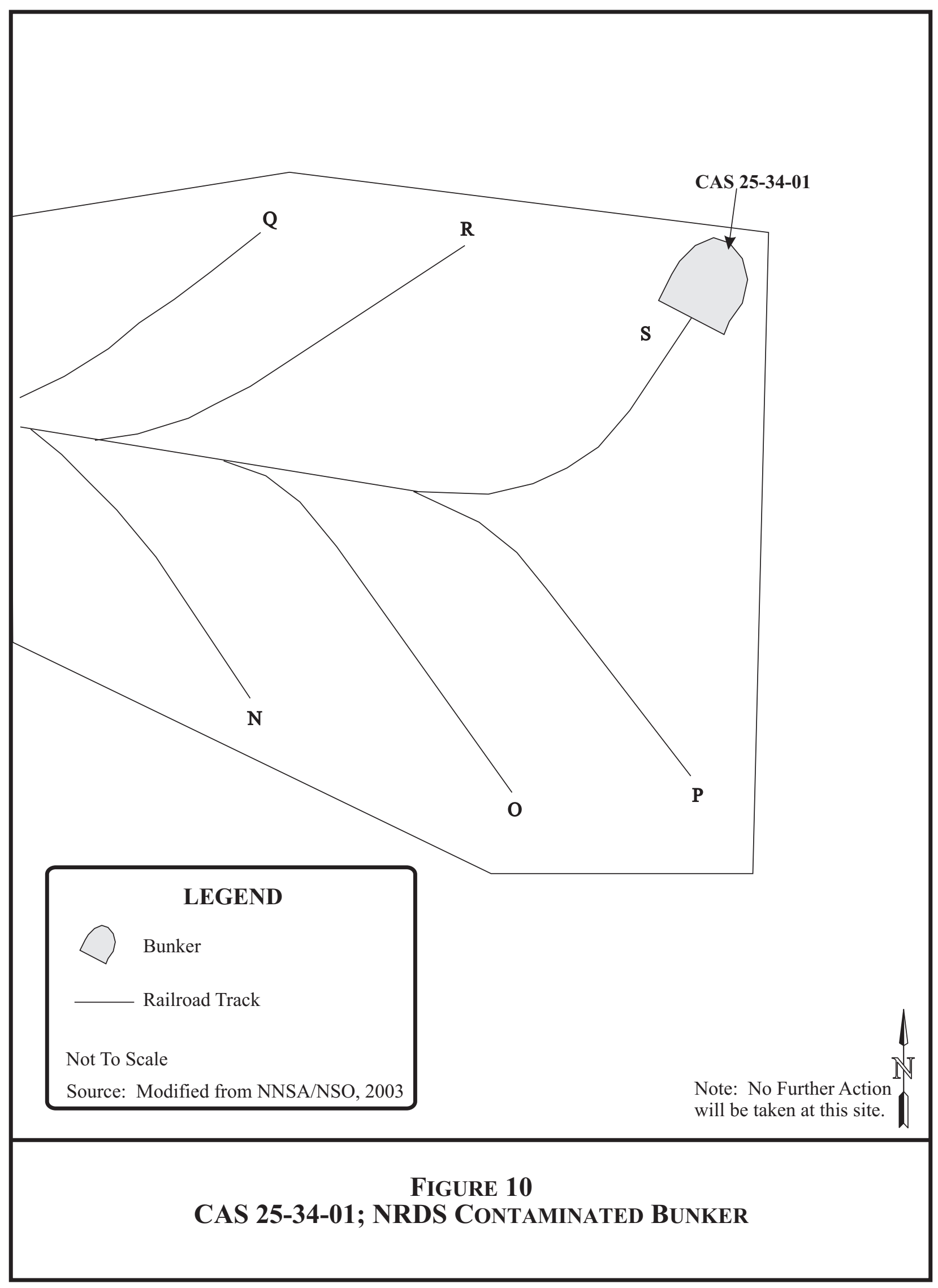




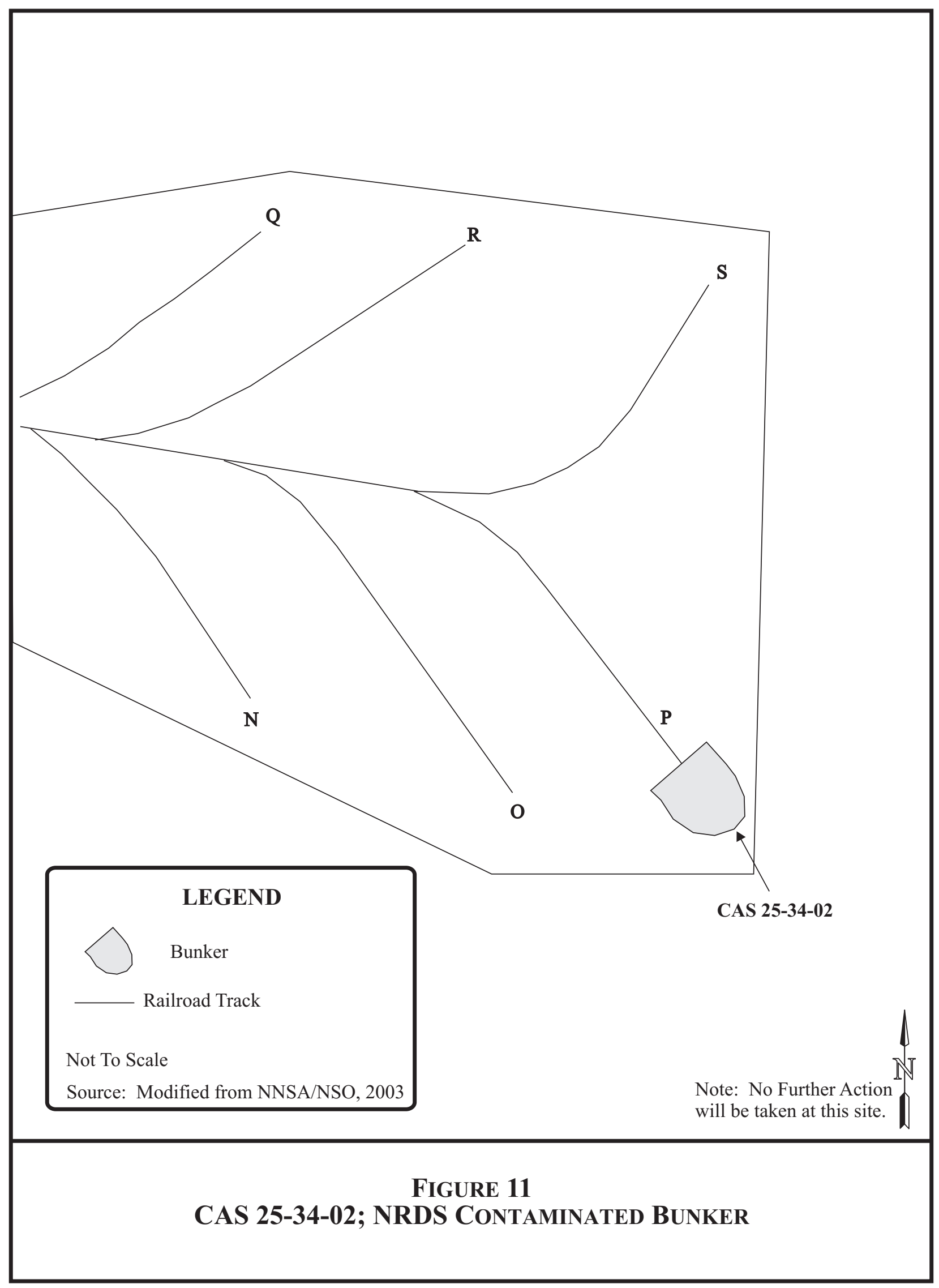




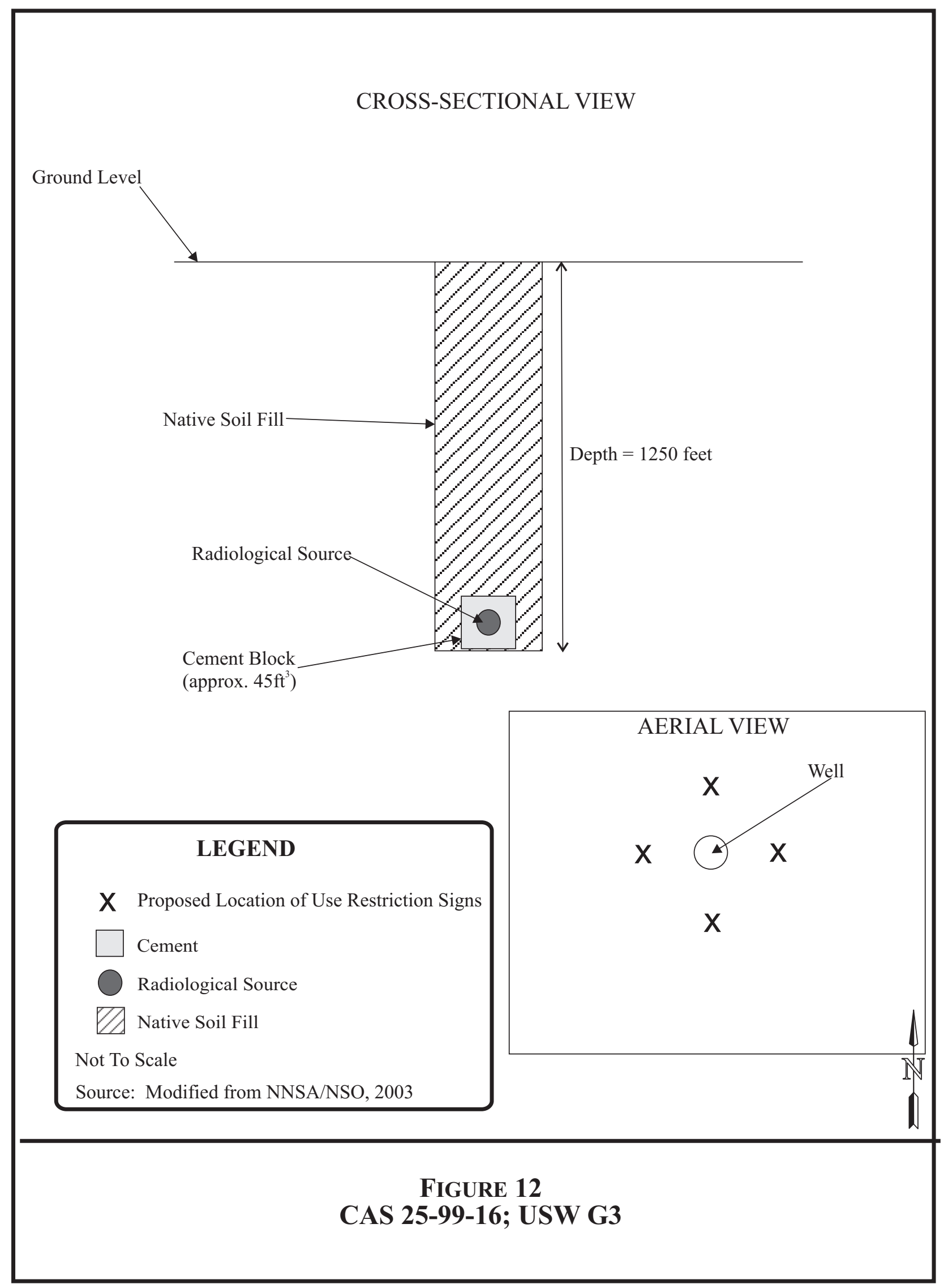




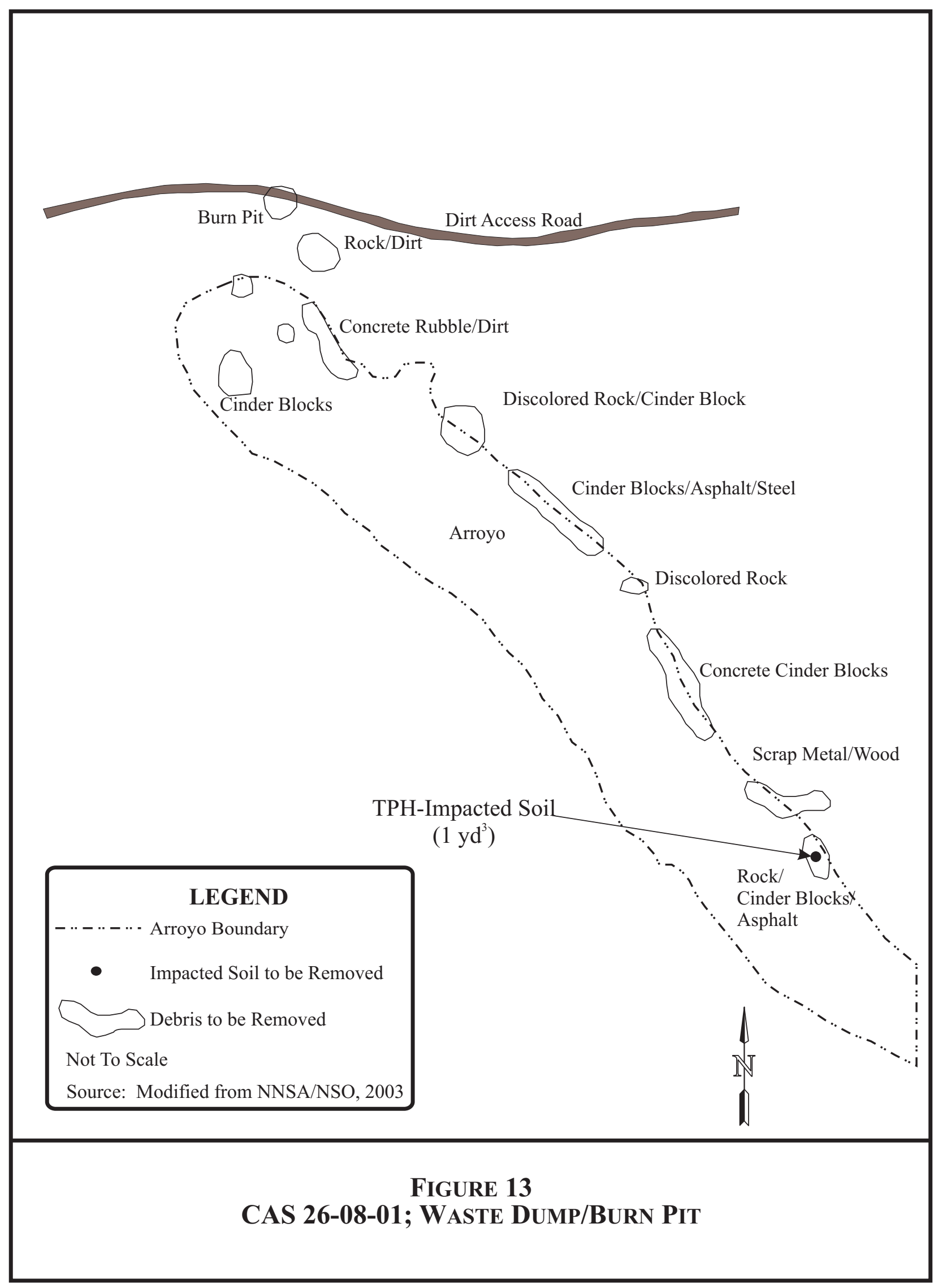




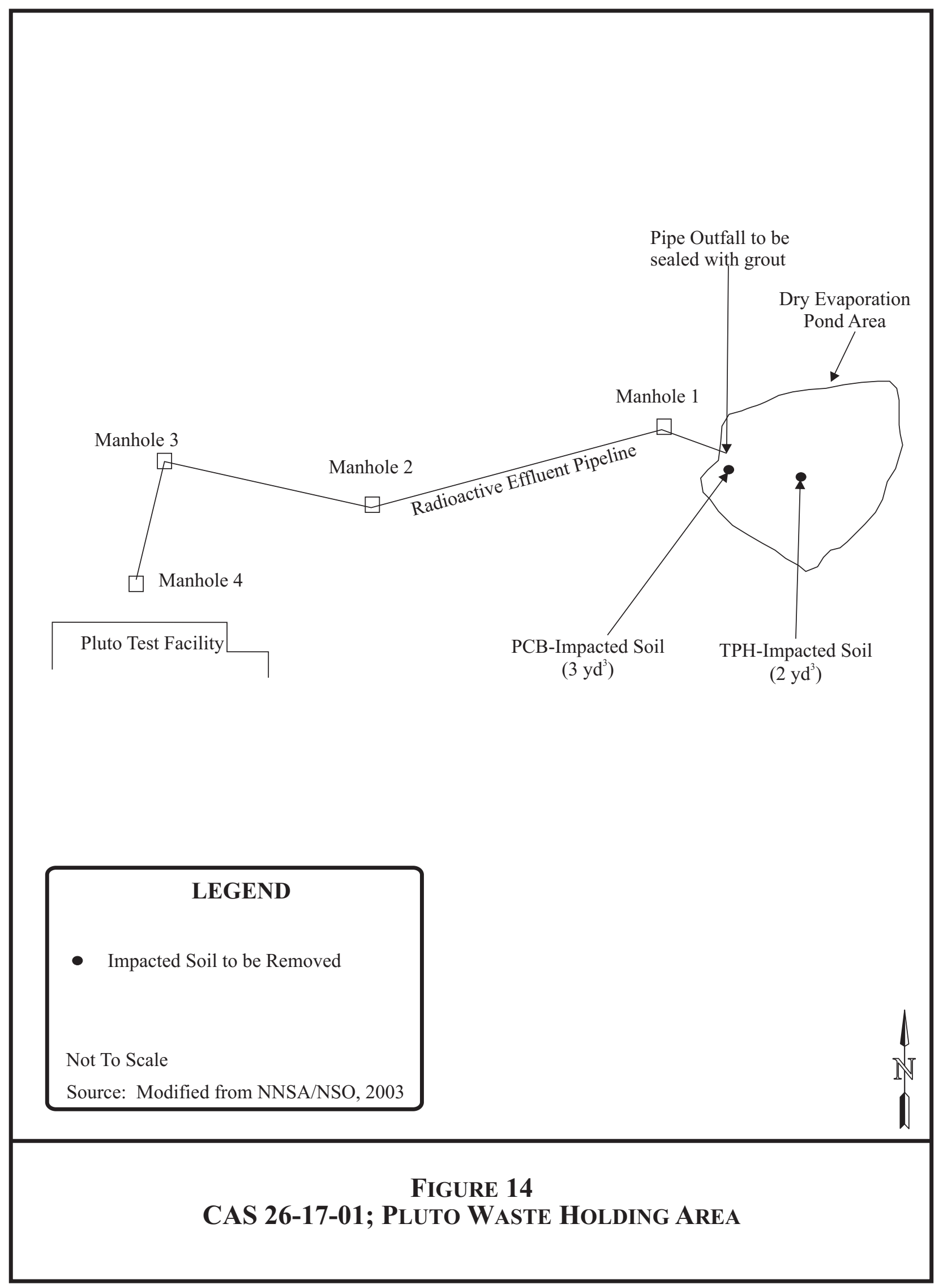




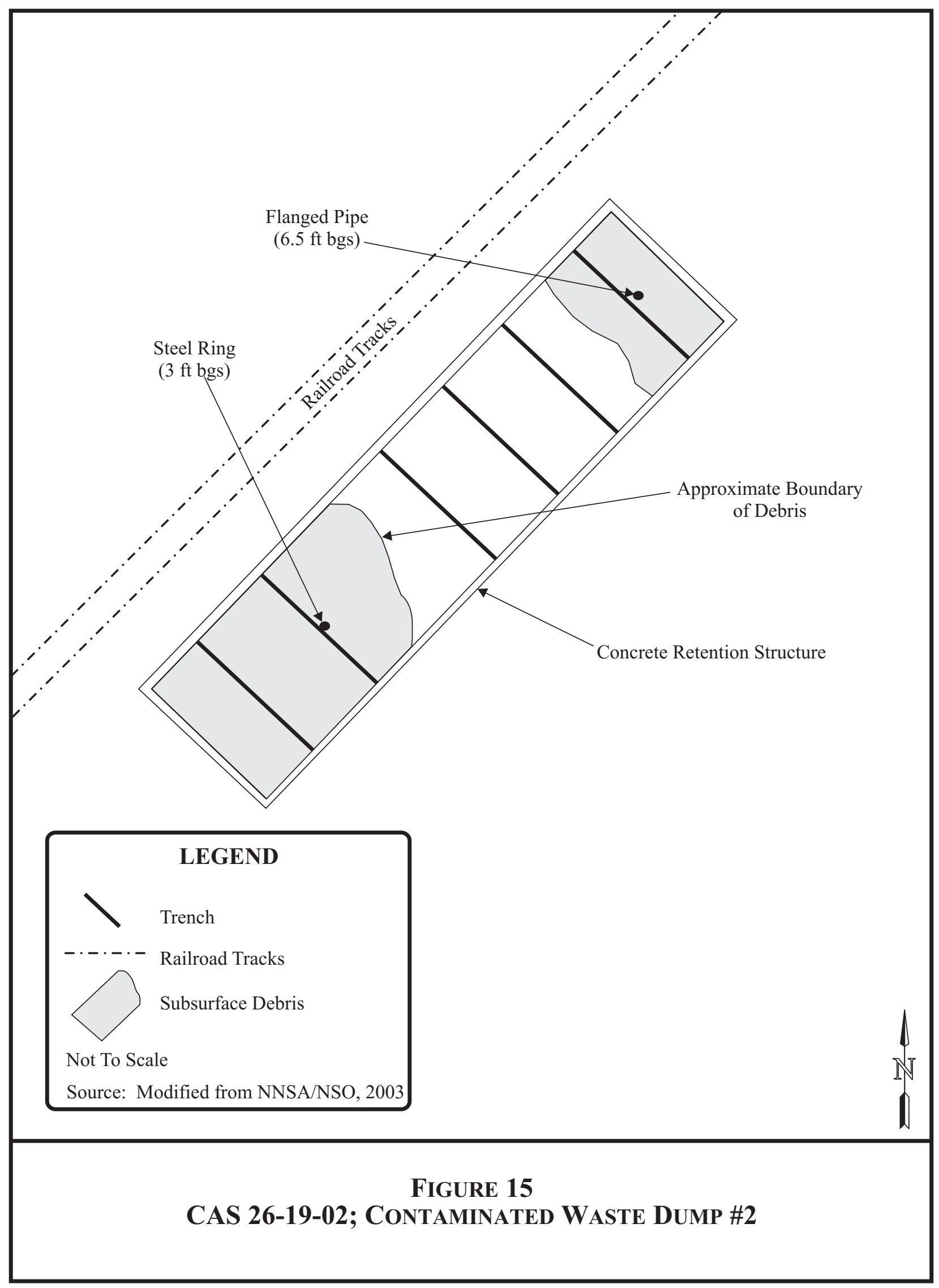


Table 1. CAU 168 Closure Activities

\begin{tabular}{|c|c|c|c|c|}
\hline CAS & Name & $\begin{array}{l}\text { Closure } \\
\text { Method }\end{array}$ & $\begin{array}{c}\text { Contaminants } \\
\text { of Concern }\end{array}$ & Scope of Work \\
\hline 25-16-01 & Construction Waste Pile & Clean Closure & ТPH & $\begin{array}{ll}\text { - } & \text { Remove and dispose of surface construction debris } \\
& \left(\text { approximately } 100 \mathrm{yd}^{3}\right) \\
\text { - } & \begin{array}{l}\text { Excavate and dispose of subsurface construction debris } \\
\left.\text { (approximately } 2105 \mathrm{yd}^{3}\right)\end{array} \\
\text { - } & \begin{array}{l}\text { Excavate and dispose of TPH-impacted soil } \\
\left(\text { approximately } 2 \mathrm{yd}^{3}\right)\end{array} \\
\text { - } & \text { Collect verification samples } \\
\text { - } & \text { Backfill excavations }\end{array}$ \\
\hline 25-16-03 & MX Construction Landfill & Closure In Place & None & $\begin{array}{ll}\text { - } & \text { Remove and dispose of metal conduit (approximately } 10 \mathrm{yd}^{3} \text { ) } \\
\text { - } & \text { Install an engineered soil cover } \\
\text { - } & \text { Install a three-strand wire fence } \\
\text { - } & \text { Post UR warning signs and implement administrative controls }\end{array}$ \\
\hline 25-19-02 & Waste Disposal Site & $\begin{array}{l}\text { No Further } \\
\text { Action }\end{array}$ & None & None \\
\hline $25-23-02$ & Radioactive Storage RR Cars & Closure In Place & $\begin{array}{l}\text { Radiological } \\
\text { Debris }\end{array}$ & - $\quad$ Post UR warning signs and implement administrative controls \\
\hline 25-23-13 & $\begin{array}{l}\text { ETL-Lab Radioactive } \\
\text { Contamination }\end{array}$ & Clean Closure & $\begin{array}{l}\text { Radiological } \\
\text { Debris }\end{array}$ & $\begin{array}{l}\text { - } \quad \text { Remove and dispose of radiologically impacted equipment, } \\
\text { ventilation system, and associated duct work } \\
\text { - } \quad \text { Perform radiological survey and decontaminate remaining } \\
\text { structure, if necessary }\end{array}$ \\
\hline 25-23-18 & Radioactive Material Storage & Clean Closure & $\begin{array}{l}\text { TPH, PCBs, lead, } \\
\text { U-234, U-235, } \\
\text { Sr-90, Cs-137 }\end{array}$ & 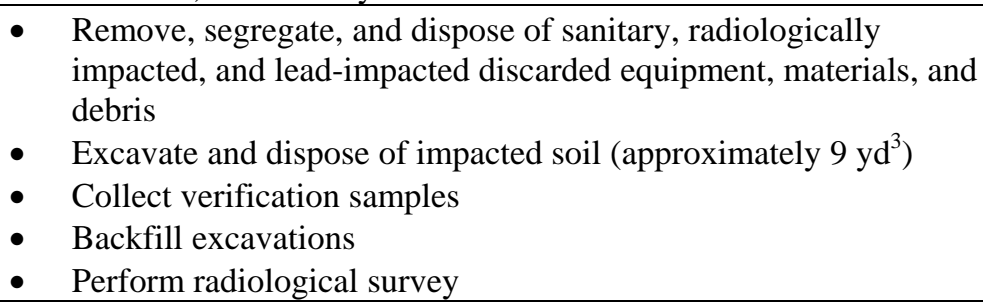 \\
\hline $25-34-01$ & NRDS Contaminated Bunker & $\begin{array}{l}\text { No Further } \\
\text { Action }\end{array}$ & None & None \\
\hline 25-34-02 & NRDS Contaminated Bunker & $\begin{array}{l}\text { No Further } \\
\text { Action }\end{array}$ & None & None \\
\hline 25-99-16 & USW G3 & Closure In Place & None & - $\quad$ Post UR warning signs and implement administrative controls \\
\hline
\end{tabular}


TABle 1. CAU 168 Closure ACtivities (CONTINUED)

\begin{tabular}{|c|c|c|c|c|}
\hline CAS & Name & $\begin{array}{l}\text { Closure } \\
\text { Method }\end{array}$ & $\begin{array}{c}\text { Contaminants } \\
\text { of Concern }\end{array}$ & Scope of Work \\
\hline 26-08-01 & Waste Dump/Burn Pit & Clean Closure & TPH, ACM & $\begin{array}{ll}\text { - } & \text { Remove, segregate, and dispose of surface debris and ACM } \\
& \left(\text { approximately } 1,100 \mathrm{yd}^{3}\right) \\
\text { - } & \text { Excavate and dispose of TPH-impacted soil } \\
& \left(\text { approximately } 1 \mathrm{yd}^{3}\right) \\
\text { - } & \text { Collect verification samples } \\
\text { - } & \text { Backfill excavation }\end{array}$ \\
\hline 26-17-01 & Pluto Waste Holding Area & Clean Closure & TPH, PCBs & 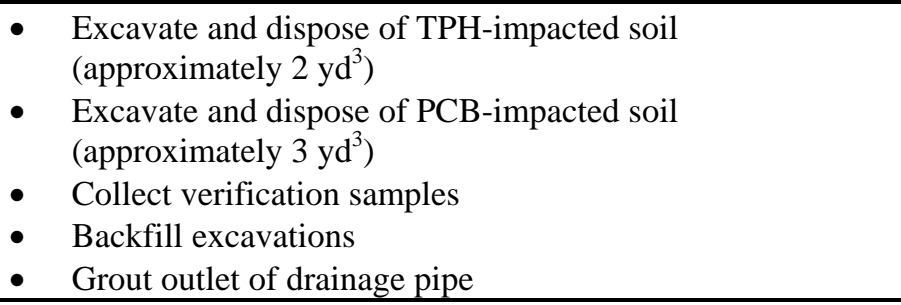 \\
\hline 26-19-02 & $\begin{array}{c}\text { Contaminated Waste } \\
\text { Dump \#2 }\end{array}$ & Clean Closure & $\begin{array}{l}\text { Radiological } \\
\text { Debris, lead }\end{array}$ & $\begin{array}{ll}\text { - } & \text { Excavate, segregate, and dispose of radiologically impacted } \\
\text { debris, solid lead items, and construction debris } \\
\text { - } & \text { Backfill excavation } \\
\text { - } & \text { Perform radiological survey and decontaminate remaining } \\
& \text { concrete retention structure, if necessary } \\
\end{array}$ \\
\hline \multicolumn{3}{|c|}{$\begin{array}{l}\text { ACM: asbestos-containing material } \\
\text { CAS: Corrective Action Site } \\
\text { Cs-137: cesium-137 } \\
\text { ETL: Engine Test Laboratory } \\
\text { MX: Missile Experiment } \\
\text { NRDS: Nuclear Rocket Development Station } \\
\text { PCBs: polychlorinated biphenyls } \\
\text { RR: railroad }\end{array}$} & $\begin{array}{l}\text { Sr-90 } \\
\text { TPH } \\
\text { U-23 } \\
\text { U-23 } \\
\text { UR: } \\
\text { USW } \\
\text { yd }^{3}:\end{array}$ & $\begin{array}{l}\text { strontium-90 } \\
\text { total petroleum hydrocarbons } \\
\text { : uranium-234 } \\
\text { : uranium-235 } \\
\text { ise restriction } \\
\text { Underground Southern Nevada Well } \\
\text { ubic yard(s) }\end{array}$ \\
\hline
\end{tabular}




\subsection{CAP CONTENTS}

This CAP is comprised of the following sections and appendices:

- $\quad$ Section 1.0 - Introduction

- $\quad$ Section 2.0 - Detailed Scope of Work

- $\quad$ Section 3.0 - Schedule

- $\quad$ Section 4.0 - Post-Closure Plan

- $\quad$ Section 5.0 - References

- $\quad$ Appendix A.1 - Engineering Specifications and Drawings

- Appendix A.2 - Sampling and Analysis Plan

- $\quad$ Appendix A.3 - Project Organization

- $\quad$ Library Distribution List

Appendix A.2 is included in this CAP as required by the FFACO outline but does not contain any material. Sufficient detail on the type, number, and location of verification samples to be collected to verify site closure activities has been provided in Section 2.4.2 of this report.

This report was primarily developed using information and guidance from the following documents:

- Federal Facility Agreement and Consent Order (FFACO, 1996)

- $\quad$ CAU 168 CAIP (NNSA/NV, 2001)

- $\quad$ CAU 168 CADD (NNSA/NSO, 2006) 
CAP - CAU 168

Section: Introduction

Revision: 1

Date: December 2006

\section{THIS PAGE INTENTIONALLY LEFT BLANK}




\subsection{DETAILED SCOPE OF WORK}

\subsection{CORRECTIVE ACTIONS}

The corrective action alternatives for each CAS are identified in the CADD (NNSA/NSO, 2006) and have been approved by the Nevada Division of Environmental Protection (NDEP). The approved alternatives include no further action, clean closure, and closure in place with administrative controls. The objectives of the corrective action alternatives are to prevent or mitigate adverse environmental impacts due to exposure and migration of surface and subsurface contamination. The specific tasks to be completed for each CAS are presented in the following sections. Figure 4 through Figure 15 provide details for each of the twelve CASs.

\subsubsection{Alternative 1 - No Further Action}

No further action will be conducted at the following sites, as no COCs were identified during site characterization (NNSA/NSO, 2006):

- $\quad$ CAS 25-19-02, Waste Disposal Site (Figure 6)

- $\quad$ CAS 25-34-01, NRDS Contaminated Bunker (Figure 10)

- $\quad$ CAS 25-34-02, NRDS Contaminated Bunker (Figure 11)

\subsubsection{Alternative 2 - Clean Closure}

Table 2 lists the cleanup criteria for CAU 168. Confirmation of achieving site closure objectives is discussed in Section 2.4 of this report.

TABle 2. CleANup CRITERIA FOR CAU 168

\begin{tabular}{|c|c|c||}
\hline Contaminant of Concern & Cleanup Action Level & Reference \\
\hline \hline Total Petroleum Hydrocarbons & $100 \mathrm{mg} / \mathrm{kg}$ & NAC, 2002 \\
\hline Polychlorinated Biphenyls & $0.7 \mathrm{mg} / \mathrm{kg}$ & EPA, 2003 \\
\hline Cesium-137 & $12.2 \mathrm{pCi} / \mathrm{g}$ & NDEP, 2004 \\
\hline Uranium-234 & $143 \mathrm{pCi} / \mathrm{g}$ & NDEP, 2004 \\
\hline Uranium-235 & $17.6 \mathrm{pCi} / \mathrm{g}$ & NDEP, 2004 \\
\hline Strontium-90 & $838 \mathrm{pCi} / \mathrm{g}$ & NDEP, 2004 \\
\hline
\end{tabular}

EPA: U.S. Environmental Protection Agency $\mathrm{mg} / \mathrm{kg}$ : milligrams per kilogram

NAC: Nevada Administrative Code

NDEP: Nevada Division of Environmental Protection

pCi/g: picoCuries per gram

\subsubsection{CAS 25-16-01, Construction Waste Pile}

The site is located approximately 152 meters (m) (500 feet [ft]) south of the Engine Maintenance, Assembly, and Disassembly (E-MAD) Facility (Figure 4). The site consists of two areas (Target Area 1 and Target Area 2). Target Area 1 consists of approximately 1,617 cubic meters $\left(\mathrm{m}^{3}\right)\left(2,100\right.$ cubic yards $\left.\left[\mathrm{yd}^{3}\right]\right)$ of subsurface construction debris, approximately $77 \mathrm{~m}^{3}$ 
$\left(100 \mathrm{yd}^{3}\right)$ of debris in a small mound, and approximately $1.5 \mathrm{~m}^{3}\left(2 \mathrm{yd}^{3}\right)$ of soil impacted with total petroleum hydrocarbons (TPH). Target Area 2 consists of approximately $3.85 \mathrm{~m}^{3}\left(5 \mathrm{yd}^{3}\right)$ of subsurface construction debris. Clean closure will be accomplished by removal and disposal of construction debris and TPH-impacted soil.

The TPH-impacted soil is located in the northern portion of Target Area 1 and will be excavated and properly disposed at the Area 6 Hydrocarbon Landfill. The extent of the excavation will be guided by field screening results for TPH. A minimum of five verification samples, one from each side wall and one from the floor, will be collected and analyzed for TPH. If verification sample results indicate that the action level is exceeded, additional soil will be removed, and additional verifications samples will be collected. Upon verifying that the TPH-impacted soil has been removed, the excavation will be backfilled with clean soil and contoured to the approximate surrounding grade.

\subsubsection{CAS 25-23-13, ETL-Lab Radioactive Contamination}

The site consists of radiologically impacted equipment, rooftop vents, a high-efficiency particulate air (HEPA) ventilation system, and associated duct work located in Building 25-3124, the Engine Test Laboratory (ETL). Table 3 lists the radiologically impacted equipment in the facility. The site will be clean closed by removing and properly disposing of the radiologically impacted equipment, ventilation system, and associated duct work (internal and external) to the facility. A schematic of the building showing the relative locations of the equipment to be removed is presented in Figure 8. If necessary to facilitate the removal and disposal of the contaminated equipment listed in Table 3, non-contaminated items and materials may need to be removed and disposed as sanitary waste. This may include partial or complete demolition of the building. If residual contamination is determined to be present in areas where the contaminated equipment resided, the impacted area(s) will be decontaminated to surface contamination limits specified in the Nevada/Yucca Mountain Project (NV/YMP) Radiological Control Manual (U.S. Department of Energy, Nevada Operations Office [DOE/NV], 2004). Decontamination will continue until levels are below the NV/YMP Radiological Control Manual limits.

TABle 3. ETL-LAB RAdioActive Contamination, EquiPMENT to BE REMOVED

\begin{tabular}{||c|c||}
\hline Equipment Item & Location \\
\hline \hline Posted Fume Hood & Clean Room \\
\hline Oven & Clean Room \\
\hline Paddle Mixer & Flow Bay \\
\hline Non-posted Fume Hood & Interior of Building \\
\hline Twin Shell Dry Blender & Flow Bay \\
\hline Rooftop HEPA units & Interior/Exterior of Building \\
\hline
\end{tabular}

\subsubsection{CAS 25-23-18, Radioactive Material Storage}

The site is located in the Radioactive Material Storage Facility (RMSF) north of the turnoff from Road $\mathrm{H}$ to the E-MAD Facility and is composed of approximately 140 acres within two fenced perimeters (Figure 9). Seven railroad (RR) spurs extending from a main RR line exist within the inner chainlink fence. The site contains various sanitary and radiologically impacted discarded equipment and materials including fifteen steel storage casks; two gas cylinders; a pallet of 
dicalite bags located on the blue flatcar on RR spur "S;" a discarded equipment/materials pile including solid lead items located between RR spurs " $M$ " and "N;" a transportainer containing a drum labeled "lithium hydride," HEPA filters, a vacuum cleaner, bagged electrical cables, and other miscellaneous equipment parts; and other miscellaneous surface debris. The site also consists of soil impacted with TPH, polychlorinated biphenyls (PCBs), and radiological COCs including uranium-234 (U-234), uranium-235 (U-235), strontium-90 (Sr-90), and cesium-137 (Cs-137).

Two TPH-impacted areas were identified. The first is located between the RR tracks in the South Bunker and is approximately $1.5 \mathrm{~m}^{3}\left(2 \mathrm{yd}^{3}\right)$ in volume. The second TPH-impacted area is located at the footprint of the discarded equipment pile between RR spurs " $M$ " and " $N$ " and is approximately $1.5 \mathrm{~m}^{3}\left(2 \mathrm{yd}^{3}\right)$ in volume. The PCB-impacted area is located near RR spur " $Q$ ” and is approximately $0.8 \mathrm{~m}^{3}\left(1 \mathrm{yd}^{3}\right)$ in volume (Figure 9$)$.

Radiologically impacted soil areas were discovered in four locations (Figure 9). The total volume of radiologically impacted soil is approximately $3 \mathrm{~m}^{3}\left(4 \mathrm{yd}^{3}\right)$. Radiological contamination was confined to a few scattered hotspot locations on the ground surface near various RR spurs and abandoned equipment areas. U-234, U-235, and Cs-137 were discovered at one surface location outside of the chainlink fence on the west side of the site. Sr-90 and Cs-137 were found near RR spur "O.” Cs-137 was found near RR spurs "S” and "M.”

Closure activities will consist of removal and proper disposal of the discarded equipment and materials and impacted soil. Radiological surveys will be conducted on the equipment and materials to segregate radiologically impacted items from sanitary waste. The extent of excavations of TPH-impacted soil will be guided by field screening results for TPH. Radiological surveys of the soil will provide data to determine the extent of the excavations at radiologically impacted soil locations. For removal of soil areas impacted at the surface to a depth of 6 inches, a minimum of two verification samples, one from a randomly selected sidewall and one from the floor, will be collected and analyzed. If the impacted area exceeds 6 inches in depth, a minimum of five verification samples, one from each sidewall and one from the floor, will be collected and analyzed. If verification sample results indicate that an action level identified in Table 2 of this report is exceeded, additional soil will be removed, and additional verifications samples will be collected. Upon verifying that the impacted soil has been removed, the excavations will be backfilled with clean soil and contoured to the approximate surrounding grade. A radiological survey of the area will be performed after closure activities, and, if possible, the footprint of the inner fenced area will be reduced.

\subsubsection{CAS 26-08-01, Waste Dump/Burn Pit}

The site is located east of Building 26-2203 in Area 26 of the NTS (Figure 13) and consists of a waste dump containing approximately $0.7 \mathrm{~m}^{3}\left(1 \mathrm{yd}^{3}\right)$ of TPH-impacted soil and approximately $847 \mathrm{~m}^{3}\left(1,100 \mathrm{yd}^{3}\right)$ of surface construction debris and asbestos-containing material (ACM). The surface debris and ACM is scattered approximately $240 \mathrm{~m}(800 \mathrm{ft})$ along the top and bottom of a sloped arroyo and includes discolored rocks, rusted drums/cans, rebar, concrete, cinder blocks, asphalt, wood, steel, and wire.

Closure activities will consist of excavation and disposal of TPH-impacted soil and removal, segregation, and disposal of surface debris and ACM. The extent of excavation of TPH-impacted soil will be guided by field screening results for TPH. A minimum of five verification samples, one from each side wall and one from the floor of the excavation, will be collected and analyzed. If verification sample results indicate that the action level is exceeded, 
additional soil will be removed, and additional verifications samples will be collected. Upon verifying that the TPH-impacted soil has been removed, the excavation will be backfilled with clean soil and contoured to the approximate surrounding grade.

\subsubsection{CAS 26-17-01, Pluto Waste Holding Area}

The site is located northeast of Building 26-2203 in Area 26 of the NTS (Figure 14). The site consists of $90 \mathrm{~m}$ (300 ft) of buried clay pipe, a small concrete wall at the pipe outfall, and an evaporation pond. Within the evaporation pond, approximately $1.5 \mathrm{~m}^{3}\left(2 \mathrm{yd}^{3}\right)$ of TPH-impacted soil and approximately $2.1 \mathrm{~m}^{3}\left(3 \mathrm{yd}^{3}\right)$ of PCB-impacted soil is present.

Closure activities will consist of sealing the outfall pipe and excavating and disposing of TPH- and PCB-impacted soil. The extent of excavation of TPH-impacted soil will be guided by field screening results for TPH. If an excavation is less than 6 inches in depth, a minimum of two verification samples, one from a randomly selected sidewall and one from the floor, will be collected and analyzed. If an excavation exceeds 6 inches in depth, a minimum of five verification samples, one from each sidewall and one from the floor, will be collected and analyzed. If verification sample results indicate that an action level is exceeded, additional soil will be removed, and additional verifications samples will be collected. Once verification sample results indicate that concentrations of contaminants remaining onsite are below action levels, the excavations will be backfilled with clean fill and contoured to the approximate surrounding grade.

\subsubsection{CAS 26-19-02, Contaminated Waste Dump \#2}

The site is located approximately $480 \mathrm{~m}$ (1,600 ft) southwest of Building 26-2203 in Area 26 of the NTS and consists of buried debris in a concrete retention structure (Figure 15). The buried debris consists of radiologically impacted items including a 0.9-m (3-ft) diameter steel ring and a 1.5-m (5-ft) long, 0.3-m (1-ft) diameter flanged steel pipe, solid lead items, and approximately $462 \mathrm{~m}^{3}\left(600 \mathrm{yd}^{3}\right)$ of construction debris. No COCs were identified in the soil; however, if soil contamination is identified by radiological surveys during closure activities, the soil will be properly disposed. Closure activities will consist of removal, segregation, and disposal of the construction debris, solid lead items, and radiologically impacted articles. A radiological survey of the remaining concrete retention structure will be performed. Areas of residual contamination that are above the surface contamination limits specified in the NV/YMP Radiological Control Manual will be decontaminated using appropriate methods (DOE/NV, 2004). The excavation will then be backfilled with clean fill and graded to the approximate surrounding grade. Clean overburden soil may be used as backfill material. A final radiological survey will be completed after closure activities.

\subsubsection{Alternative 3 - Close in Place with Administrative Controls}

\subsubsection{CAS 25-16-03, MX Construction Landfill}

This site consists of two subsurface disposal cells containing buried construction debris (Figure 5). Approximately $0.7 \mathrm{~m}^{3}\left(10 \mathrm{yd}^{3}\right)$ of metal conduit is present on the surface and will be removed and disposed as a best management practice. Process knowledge confirms that no hazardous or radioactive waste was buried at the site, and no COCs were identified at this site during site characterization (NNSA/NSO, 2006). 
The site will be closed in place, and a use restriction (UR) will be implemented to prohibit any unauthorized intrusive activity. An engineered soil cover will be installed with a minimum

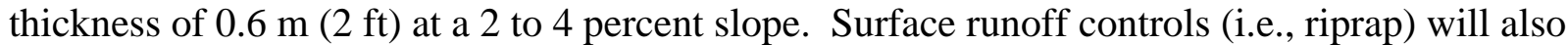
be put in place. UR warning signs will be posted, and a three-strand wire fence will be installed. The corrective actions will be confirmed by visual inspection and photographic documentation of the final site conditions, and the cover will be as-built surveyed. Annual site inspections will be required to ensure that the signs are intact and legible and that the UR is maintained (Section 4.0).

\subsubsection{CAS 25-23-02, Radioactive Storage RR Cars}

This site includes nineteen RR cars located within the inner perimeter fencing of the RMSF on six of the seven RR spurs in the yard (Figure 7). The RR cars will be closed in place, and a UR will be implemented to prohibit any unauthorized intrusive activity and restrict access to the RR cars. UR warning signs will be posted to communicate the UR. The corrective actions will be confirmed by visual inspection and photographic documentation of the final site conditions. Annual site inspections will be required to ensure that the signs are intact and legible and that the UR is maintained (Section 4.0).

\subsubsection{CAS 25-99-16, USW G3}

This site contains a radiological source that was entombed in a subsurface borehole/well (Figure 12). A review of historical documentation did not indicate any COCs were likely to be present. No site characterization was completed (NNSA/NSO, 2006). The site will be closed in place, and a UR will be implemented to prohibit unauthorized intrusive activity. UR warning signs will be posted. The corrective actions will be confirmed by visual inspection and photographic documentation of the final site conditions. Annual site inspections will be required to ensure that the signs are intact and legible and that the UR is maintained (Section 4.0).

\subsection{CONSTRUCTION QUALITY ASSURANCE/QUALITY CONTROL}

Construction activities are limited to excavation and backfilling, debris removal, site posting, and the installation of a native soil cover over the existing footprint of the construction landfill at CAS 25-16-03, MX Construction Landfill. Engineering drawings for the landfill cover at CAS 25-16-03 are provided in Appendix A.

\subsubsection{Construction Field Sample Collection Activities}

Soil samples will be collected for the purpose of waste stream characterization and to verify that the closure objectives have been met. Sample collection activities are addressed in Section 2.4 of this report.

At CAS 25-16-03, MX Construction Landfill, field density tests will be performed in three randomly selected locations per acre in the first 8-inch layer of soil to verify that the fill is compacted to a minimum of 85 percent density. After it is verified that the compaction method used in the first layer of soil meets this standard, the remaining layers will be compacted by the same means as the first layer. 


\subsubsection{Construction Laboratory/Analytical Data Quality Indicators}

CAU 168 closure activities are limited to debris removal, site posting, non-structural excavation and backfilling, and the installation of a native soil cover. Therefore, a construction quality assurance/quality control (QA/QC) plan is not required, and construction data quality indicators (DQIs) are not applicable.

\subsection{WASTE MANAGEMENT}

All waste will be managed and disposed according to applicable federal and state regulations, U.S. Department of Energy (DOE) Orders, and National Security Technologies, LLC, (NSTec) procedures. CAU 168 closure activities are expected to generate TPH waste, sanitary waste/construction debris, Toxic Substances Control Act (TSCA)-regulated waste, hazardous waste (HW), mixed waste (MW), ACM, and/or low-level waste (LLW). Confirmation of waste disposal will be included in the CAU 168 Closure Report (CR).

\subsubsection{TPH Waste}

TPH waste is anticipated to be generated at CAS 25-16-01 (Construction Waste Pile), CAS 25-23-18 (Radioactive Material Storage), CAS 26-08-01 (Waste Dump/Burn Pit), and CAS 26-17-01 (Pluto Waste Holding Area). All TPH waste will be screened for gamma-emitting radionuclides by In-Situ Object Counting System (ISOCS) analysis and/or laboratory analysis prior to disposal, if required. Upon receipt of the analytical results, the waste will be transported to the Area 6 Hydrocarbon Landfill for disposal.

\subsubsection{Sanitary Waste/Construction Debris}

Sanitary waste (e.g., non-impacted personal protective equipment [PPE] and general trash) and construction debris (e.g., wood, concrete, block, metal, and plastic) removed from sites will be randomly screened for radiological contamination. Once it is verified that the waste meets landfill acceptance criteria, it will be disposed appropriately in an onsite landfill.

\subsubsection{TSCA-Regulated Waste}

PCB waste is anticipated to be produced during the closure activities at CAS 26-17-01 (Pluto Waste Holding Area) and CAS 25-23-18 (Radioactive Material Storage). PCBs are classified by TSCA as a toxic waste and will be managed as such. All work shall follow the Title 40 Code of Federal Regulations 761, "Polychlorinated Biphenyls Manufacturing, Processing, Distribution in Commerce, and Use Prohibitions” (U.S. Environmental Protection Agency [EPA], 2003). The waste will be managed in a waste accumulation area onsite in appropriate containers. The waste will then be characterized by sampling and a profile for disposal prepared, if required. If required, the waste will be shipped to an approved offsite treatment, storage, and disposal (TSD) facility for disposal.

\subsubsection{Hazardous Waste}

HW is anticipated to be generated at CAS 26-19-02 (Contaminated Waste Dump \#2) and CAS 25-23-18 (Radioactive Material Storage) in the form of solid lead and lithium hydride. HW will be properly characterized, packaged, and transported for disposal to a permitted offsite TSD 
facility. HW will be managed according to Company Document CD-0442.006, "Hazardous Waste Management” (Bechtel Nevada [BN], 2006).

\subsubsection{Mixed Waste}

MW may be generated at CAS 26-19-02 (Contaminated Waste Dump \#2) and/or CAS 25-23-18 (Radioactive Material Storage) in the form of contaminated solid lead if radiological survey results indicate that the lead does not meet landfill disposal limits. If MW is generated, it will be properly characterized, packaged, and transported for disposal at a permitted offsite TSD facility.

\subsubsection{Asbestos-Containing Material}

ACM will be generated at CAS 26-08-01 (Waste Dump/Burn Pit). At this site, ACM will be segregated from construction debris, packaged, and transported to the Area 23 Sanitary Landfill for disposal.

\subsubsection{Low-Level Waste}

LLW will be generated during CAU 168 closure activities in the form of radiologically impacted soil and debris. All LLW will be characterized by process knowledge, ISOCS analysis, laboratory analysis, and/or radiological screening, and a profile for disposal will be prepared. All LLW will be stored in radioactive materials areas and packaged in approved containers. After approval of a waste profile, the LLW will be transported to an appropriate onsite disposal facility.

\subsubsection{Decontamination Waste}

All equipment used in a contamination area (CA) will be surveyed prior to release from the CA. Any equipment that becomes radiologically contaminated during closure activities will be decontaminated onsite. Dry decontamination will be the preferred method. For larger pieces of equipment that cannot be effectively decontaminated using dry decontamination techniques, wet decontamination techniques shall be used over a drum or waste pile. For equipment that cannot be decontaminated over a drum or waste pile, a decontamination pad will be constructed by lining a bermed area large enough to hold the equipment. The equipment will be cleaned using a pressure washer/steam cleaner or rinsed. The rinsate will be solidified by mixing with clean soil. Smaller equipment and/or tools will be decontaminated with soap and water. If a decontamination pad is constructed, the plastic liner will be radiologically surveyed upon completion of the closure activities. The liner will be disposed at an appropriate disposal facility. Equipment impacted with PCBs will be decontaminated by double washing the equipment with soap and double rinsing with water under pressure. All rinsate, after solidification, will be characterized by sampling, and properly disposed.

\subsubsection{Personal Protective Equipment}

All PPE that becomes contaminated during closure activities will be disposed with the appropriate waste stream. All waste generated during closure activities will be properly disposed in either onsite landfills or at a permitted offsite TSD facility. 


\subsubsection{Waste Minimization}

All work activities that generate waste will follow the NSTec waste minimization and pollution prevention program. Special care will be given to properly characterize and segregate the waste streams to avoid the generation of additional waste. Field test kits and radiological survey instruments will be used to guide excavations and minimize quantities of TPH-, PCB-, and radiologically impacted soil. The use of manual and mechanical equipment (e.g., front end loaders, dozers, excavators, grapple jaws, and screens) to segregate the debris from the soil will be used to minimize waste and optimize re-use of the segregated soil for backfill and area grading.

\subsection{CONFIRMATION OF CORRECTIVE ACTIONS}

Accurate and defensible analytical data will be collected to characterize waste and verify that the closure criteria have been met.

\subsubsection{No Further Action Sites}

No closure activities have been identified for the following sites, and confirmation of corrective action will not be required.

- $\quad$ CAS 25-19-02, Waste Disposal Site

- $\quad$ CAS 25-34-01, NRDS Contaminated Bunker (North Bunker)

- $\quad$ CAS 25-34-02, NRDS Contaminated Bunker (South Bunker)

\subsubsection{Clean Closure Sites}

Impacted soil will be removed from CAS 25-16-01 (Construction Waste Pile), CAS 25-23-18 (Radioactive Material Storage), CAS 26-08-01 (Waste Dump/Burn Pit), and CAS 26-17-01 (Pluto Waste Holding Area). The size and extent of the excavations will be guided by use of field screening instrumentation and/or test kits. After field screening indicates that impacted material is no longer present, verification soil samples will be collected from the excavations and submitted to an offsite laboratory for analysis. If analytical results for verification samples exceed the cleanup action levels listed in Table 2 of this document, additional soil will be removed from the area, and additional verification samples will be collected.

All samples will be collected by hand using disposable pre-cleaned or decontaminated sampling equipment (BN, 2002b). Samples will be collected directly from the excavation locations indicated in the following sections, or if the excavation poses a safety hazard to sampling personnel, from the center of a backhoe bucket of soil collected from the indicated locations. All samples will be collected in clean containers, labeled appropriately, sealed with a tamper seal, bagged, and placed on ice in a cooler for transport under a completed chain-of-custody (BN, 2002a). Samples will be analyzed by an approved offsite laboratory. Sample analysis will include laboratory analysis of QA/QC samples and will follow stringent QA/QC procedures. In addition, all sample analytical data will be reviewed and validated using data validation procedures. Any data determined not to be valid will be identified in the CR.

All samples will be labeled with a unique sample identification number using the CAS number followed by the sample number (e.g., 251601-V1). Waste characterization samples will also be named by using the CAS number followed by the sample number (e.g., 251601-W1). QA/QC 
samples will be collected, including blind duplicate and matrix spike/matrix spike duplicate samples. Blind duplicate samples will be labeled with a unique sample number.

\subsubsection{CAS 25-16-01, Construction Waste Pile}

At CAS 25-16-01, corrective actions will be verified complete when the subsurface construction debris has been removed and dispositioned for proper disposal. Debris removal will be confirmed by visual inspection and photographic documentation of the excavation areas. Confirmation of TPH-impacted soil removal will be determined by verifying the analytical results for verification samples are less than the action level. The size and extent of the excavation will be guided by field screening results. A minimum of five soil samples, one from each side wall and one from the floor of the excavation, will be collected and analyzed. If analytical results for verification samples exceed action levels, additional soil will be removed from the excavation area, and additional verification samples will be collected.

\subsubsection{CAS 25-23-13, ETL-Lab Radioactive Contamination}

At CAS 25-23-13, corrective actions will include the removal of radiologically impacted equipment. Soil removal activities will not be performed at this CAS. Radiological surveys will be performed to verify removal of surface contamination. If residual contamination is present that requires decontamination, the area will be decontaminated to surface contamination limits specified in the NV/YMP Radiological Control Manual (DOE/NV, 2004).

\subsubsection{CAS 25-23-18, Radioactive Material Storage}

For CAS 25-23-18, removal and disposal of debris/discarded equipment, including sanitary waste, radiologically impacted debris, and lead, will be confirmed by visual inspection and photographic documentation. A radiological survey of the site will be performed to document final site conditions. Confirmation of impacted soil removal will be determined by verifying the analytical results for verification samples are less than the action levels specified in Table 2 of this report. The size and extent of TPH-impacted soil excavations will be guided by field screening results. The size and extent of the excavations at radiologically impacted locations will be determined by radiological survey results. For removal of soil areas impacted at the surface to a depth of 6 inches, a minimum of two verification samples, one from a randomly selected sidewall and one from the floor of the excavation, will be collected and analyzed. If the excavation exceeds 6 inches in depth, a minimum of five verification samples, one from each sidewall and one from the floor of the excavation, will be collected and analyzed. If analytical results for verification samples exceed action levels, additional soil will be removed, and additional verification samples will be collected.

\subsubsection{CAS 26-08-01, Waste Dump/Burn Pit}

At CAS 26-08-01, corrective actions will be determined complete when the surface debris has been removed and transported to an appropriate landfill for proper disposal. Sanitary debris and ACM removal will be confirmed by visual inspection and photographic documentation. Confirmation of TPH-impacted soil removal will be determined by verifying the analytical results for verification samples are less than the action level. The size and extent of the excavation will be guided by field screening results. A minimum of five soil samples, one from each side wall and one from the floor of the excavation, will be collected and analyzed. If 
analytical results for verification samples exceed action levels, additional soil will be removed, and additional verification samples will be collected.

\subsubsection{CAS 26-17-01, Pluto Waste Holding Area}

For CAS 26-17-01, confirmation of TPH- and PCB-impacted soil removal will be determined by verifying the analytical results for verification samples are less than the action levels. The size and extent of the TPH-impacted soil excavation will be guided by field screening results. For removal of soil areas impacted at the surface to a depth of 6 inches, a minimum of two verification samples, one from a randomly selected sidewall and one from the floor of the excavation, will be collected and analyzed. If the excavation exceeds 6 inches in depth, a minimum of five verification samples, one from each sidewall and one from the floor of the excavation, will be collected and analyzed. If analytical results for verification samples exceed action levels, additional soil will be removed, and additional verification samples will be collected.

\subsubsection{CAS 26-19-02, Contaminated Waste Dump \#2}

For CAS 26-19-02, corrective actions will be determined complete when all subsurface debris, including sanitary waste, radiologically impacted debris, and lead, has been removed and dispositioned for proper disposal. Debris removal will be confirmed by visual inspections and photographic documentation of the excavation area. A radiological survey of the remaining concrete retention structure will be performed. Areas of residual contamination that are above the surface contamination limits specified in the NV/YMP Radiological Control Manual will be decontaminated using appropriate methods (DOE/NV, 2004). A final radiological survey will be completed after closure activities are complete.

\subsubsection{Closure in Place with Administrative Controls Sites}

\subsubsection{CAS 25-16-03, MX Construction Landfill}

For CAS 25-16-03, corrective actions will include removal of surface debris and installation of an engineered cover, surface runoff controls, a three-strand wire fence, and UR warning signs. The corrective actions will be confirmed by visual inspection and photographic documentation of the final site conditions.

\subsubsection{CAS 25-23-02, Radioactive Storage RR Cars}

For CAS 25-23-02, corrective actions will include installation of UR warning signs. The corrective actions will be confirmed by visual inspection and photographic documentation of the final site conditions.

\subsubsection{CAS 25-99-16, USW G3}

For CAS 25-99-16, the corrective actions will include installation of UR warning signs. The corrective action will be confirmed by visual inspection and photographic documentation of the final site conditions. 


\subsubsection{Laboratory/Analytical Data Quality Indicators}

Data Quality Objectives (DQOs) are qualitative and quantitative statements that specify the quality of the data required to support the closure of a site. The DQOs for the CAU 168 site investigation were defined in the CAIP (NNSA/NV, 2001) using the seven-step DQO process developed by the EPA (EPA, 2000). Five conceptual site models for the CAU 168 CASs were defined in the CAIP (NNSA/NV, 2001), and these models were reconciled with the results of the site investigation in the CADD (NNSA/NSO, 2006).

Sample analytical results will be generated during closure activities for CAS 25-16-01 (Construction Waste Pile), CAS 25-23-18 (Radioactive Material Storage), CAS 26-08-01 (Waste Dump/Burn Pit), and CAS 26-17-01 (Pluto Waste Holding Area). All laboratory data generated during closure activities will be reviewed by project personnel to ensure the data are usable and complete according to the CAU 168 DQOs. In addition, as specified in the Industrial Sites Quality Assurance Project Plan (NNSA/NV, 2002), the final data packages will be validated using applicable Operating Instructions (OIs). These include OI-2151.303 (BN, 2004) for validating radiological data and OI-2154.459 (BN, 2003) for validating inorganic chemical data. OI-2154.459 is based on EPA Functional Guidelines (EPA, 1994). More details on the proposed number and location of the verification samples are given in Section 2.4.2 of this report.

\section{Data Quality Indicators}

DQIs are qualitative and quantitative statements that specify the data requirements of a project. The DQIs include accuracy, comparability, completeness, precision, representativeness, and sensitivity. These DQIs are discussed below.

\section{Precision}

Precision measures the reproducibility of data under a given set of conditions. It is a quantitative measurement of the variability of a population of measurements compared to their average value. Precision applies to parameters sampled and analyzed in duplicate. One duplicate sample will be collected per set of 20 or fewer verification samples. All duplicate samples will be collected from the same medium and analyzed for the same set of analytes as verification samples. The precision of the analytical results will be assessed by calculating relative percent difference (RPD) for a verification sample and its duplicate sample results. A RPD of less than or equal to 30 percent indicates acceptable precision (NNSA/NV, 2002).

\section{Accuracy}

Accuracy measures the nearness of a measured or calculated value of a parameter to the true value of that parameter. The closer the measurement is to the true value, the more accurate the measurement. Accuracy will be assessed by examining the percent recovery of laboratory control and spiked samples. A percent recovery within the range of 70 - 130 percent indicates satisfactory analytical accuracy (NNSA/NV, 2002).

\section{Representativeness}

Representativeness is a qualitative measure of the degree to which the sample data accurately and precisely represents a characteristic of a sample population or environmental condition. This 
will be attained by ensuring that the sample locations, analytical parameters, analytical methods, sampling protocols, and sample handling all meet the project-specific objectives.

\section{Comparability}

Comparability is a qualitative measure that expresses the confidence that one data set can be compared to another. It will be achieved by using standardized field sampling procedures and same analytical methods for sample analysis. All samples will be collected using approved methods (BN, 2002a and 2002b). Sample results will be reported in standard units to allow for comparison of the data.

\section{Completeness}

Completeness is a quantitative measure of data quality expressed as the percentage of valid data obtained that satisfies the project-specific requirements. Since a limited number of samples will be collected for both waste characterization and verification of closure, 100 percent of the data collected needs to be of acceptable quality to maintain acceptable QA/QC standards.

\section{Sensitivity}

Sensitivity is the capability of a method or instrument to discriminate between measurement responses representing different levels of a variable of interest. This indicator is determined from the value of the standard deviation at the concentration level of interest. It represents the minimum difference of concentration that can be distinguished between two samples with a high degree of confidence. Sensitivity must be sufficient to detect contaminants at or below decision levels. Sensitivity will be achieved by analyzing all samples using the appropriate EPA-approved analytical laboratories, methods, and instruments.

\subsection{PERMITS}

Prior to beginning field closure activities, the following permits will be prepared:

- $\quad$ National Environmental Policy Act (NEPA) Checklist

- $\quad$ NNSA/NSO Real Estate/Operations (REOP) Permit

- $\quad$ Radiological Work Permit (RWP)

- Utility Clearances and Excavation Permit

\subsubsection{National Environmental Policy Act Checklist}

A NEPA Checklist will be completed prior to all activities. Closure activities will follow all applicable federal, state, and local laws; regulations; and permits regarding protection of the environment.

\subsubsection{NNSA/NSO Real Estate/Operations Permit}

A REOP will be obtained prior to beginning closure activities. The permit will establish the NNSA/NSO as the prime authority possessing control of the site. The REOP will establish a sole governing organization responsible for safety and identify the NNSA/NSO's responsibility to plan and schedule activities. 


\subsubsection{Radiological Work Permit}

Date: December 2006

RWPs will be required for work at radiologically impacted sites when radiological conditions require, as determined by the NSTec Health Physics Department. RWPs inform workers of the specific PPE necessary to protect them while performing their tasks and identify site-specific controls. The workers will be required to read RWPs and acknowledge their understanding of the requirements before entry into a CA. The RWPs will be maintained by Radiological Control Technicians at the entrance to a CA. All site workers will be required to obtain Radiological Worker II training to perform any work within a CA.

\subsubsection{Utility Clearances and Excavation Permits}

A utility clearance will be performed and an excavation permit obtained prior to beginning any excavation activities. A copy of the permit will be filed onsite throughout the duration of the project. 
CAP - CAU 168

Section: Detailed SOW

Revision: 1

Date: December 2006

THIS PAGE INTENTIONALLY LEFT BLANK 


\subsection{SCHEDULE}

Preparation activities occurred during July 2005, and field work began in Fiscal Year 2005. The FFACO deadline for the CR is January 31, 2007. Sufficient flexibility has been incorporated into the field schedule to allow for minor difficulties (e.g., weather and equipment failure). The NNSA/NSO shall notify the NDEP of any condition or event that may impact the project schedule. 
Revision: 1

Date: December 2006

THIS PAGE INTENTIONALLY LEFT BLANK 


\subsection{POST-CLOSURE PLAN}

A corrective action alternative of closure in place with administrative controls requires post-closure site inspections. Administrative controls will be implemented at CAS 25-16-03 (MX Construction Landfill), CAS 25-23-02 (Radioactive Storage RR Cars), and CAS 25-99-16 (USW G3) to prohibit any unauthorized intrusive activities.

\subsection{INSPECTIONS}

Annual inspections will be completed at CAS 25-16-03 (MX Construction Landfill), CAS 25-23-02 (Radioactive Storage RR Cars), and CAS 25-99-16 (USW G3) for five years. After the fifth year, inspections will be conducted every five years for twenty years. Inspections consist of visual inspections of the postings to verify they are in place and readable and that the URs have been maintained. Any identified maintenance or repair requirements will be reported to NDEP and scheduled within ninety working days of discovery. The inspection report will be incorporated into the combined annual letter report and submitted to the NDEP. The letter report will include a discussion of observations and provide a record of any repair or maintenance activities.

\subsection{MONITORING}

As no post-closure sampling or data collection will be performed, no post-closure monitoring is required at any CAS in CAU 168. However, post-closure inspections will be performed for the CASs identified above in Section 4.1.

\subsection{MAINTENANCE AND REPAIR}

If any maintenance and repair requirements are identified during the site inspection of any CAS, funding will be requested and the repairs scheduled. Any repair or maintenance performed at any CAS shall be documented in writing at the time of the repair and included in the annual letter report. 
CAP - CAU 168

Section: Post-Closure Plan

Revision: 1

Date: December 2006

THIS PAGE INTENTIONALLY LEFT BLANK 


\subsection{REFERENCES}

Bechtel Nevada, 2002a. “Sampling Chain of Custody,” Organization Instruction OI-2152.100. Las Vegas, NV.

Bechtel Nevada, 2002b. “Soil Sampling,” Organization Instruction OI-2152.108. Las Vegas, NV.

Bechtel Nevada, 2003. “Inorganic Data Verification and Validation,” Organization Instruction OI-2154.459. Las Vegas, NV.

Bechtel Nevada, 2004. "Validation of Radiological and Chemical Laboratory Data," Organization Instruction OI-2151.303. Las Vegas, NV.

Bechtel Nevada, 2006. “Hazardous Waste Management,” Company Document CD-0442.006. Las Vegas, NV.

BN, see Bechtel Nevada.

DOE/NV, see U.S. Department of Energy, Nevada Operations Office.

EPA, see U.S. Environmental Protection Agency.

Federal Facility Agreement and Consent Order, 1996 (as amended). Agreed to by the State of Nevada, the U.S. Department of Energy, and the U.S. Department of Defense.

FFACO, see Federal Facility Agreement and Consent Order.

NAC, see Nevada Administrative Code.

NDEP, see Nevada Division of Environmental Protection.

Nevada Administrative Code, 2002. 445A.2272, “Contamination of Soil: Establishment of Action Levels.” Carson City, NV.

Nevada Division of Environmental Protection, 2004. Letter to Janet Appenzeller-Wing U.S. Department of Energy, National Nuclear Security Administration Nevada Site Office, March 9, 2004.

NNSA/NSO, see U.S. Department of Energy, National Nuclear Security Administration Nevada Site Office.

NNSA/NV, see U.S. Department of Energy, National Nuclear Security Administration Nevada Operations Office.

U.S. Department of Energy, National Nuclear Security Administration Nevada Operations Office, 2001. Corrective Action Investigation Plan for Corrective Action Unit 168: 


\section{REFERENCES (continued)}

Areas 25 and 26 Contaminated Materials and Waste Dumps, Nevada Test Site, Nevada, DOE/NV--780, Las Vegas, NV.

U.S. Department of Energy, National Nuclear Security Administration Nevada Operations Office, 2002. Industrial Sites Quality Assurance Project Plan. DOE/NV--372-REV. 3, Las Vegas, NV.

U.S. Department of Energy, National Nuclear Security Administration Nevada Site Office, 2006. Corrective Action Decision Document for Corrective Action Unit 168: Areas 25 and 26 Contaminated Materials and Waste Dumps, Nevada Test Site, Nevada.

DOE/NV--882-REV. 2, Las Vegas, NV.

U.S. Department of Energy, Nevada Operations Office, 2004. NV/YMP Radiological Control Manual, Revision 5. DOE/NV/11718--079, Las Vegas, NV.

U.S. Environmental Protection Agency, 1994. Laboratory Data Validation Functional Guidelines for Evaluating Inorganic Analyses. EPA/540/R-94/083, Washington D.C.

U.S. Environmental Protection Agency, 2000. Guidance for Data Quality Objectives Process. EPA QA/G-4, EPA/600/R-96/055, Washington D.C.

U.S. Environmental Protection Agency, 2003. Title 40, Code of Federal Regulations, 761, Polychlorinated Biphenyls, Manufacturing, Processing, Distribution in Commerce, and Use Prohibitions. Washington D.C. 


\section{APPENDIX A.1}

\section{ENGINEERING SPECIFICATIONS AND DRAWINGS}


CAP - CAU 168

Section: Appendix A.1

Revision: 1

Date: December 2006

THIS PAGE INTENTIONALLY LEFT BLANK 


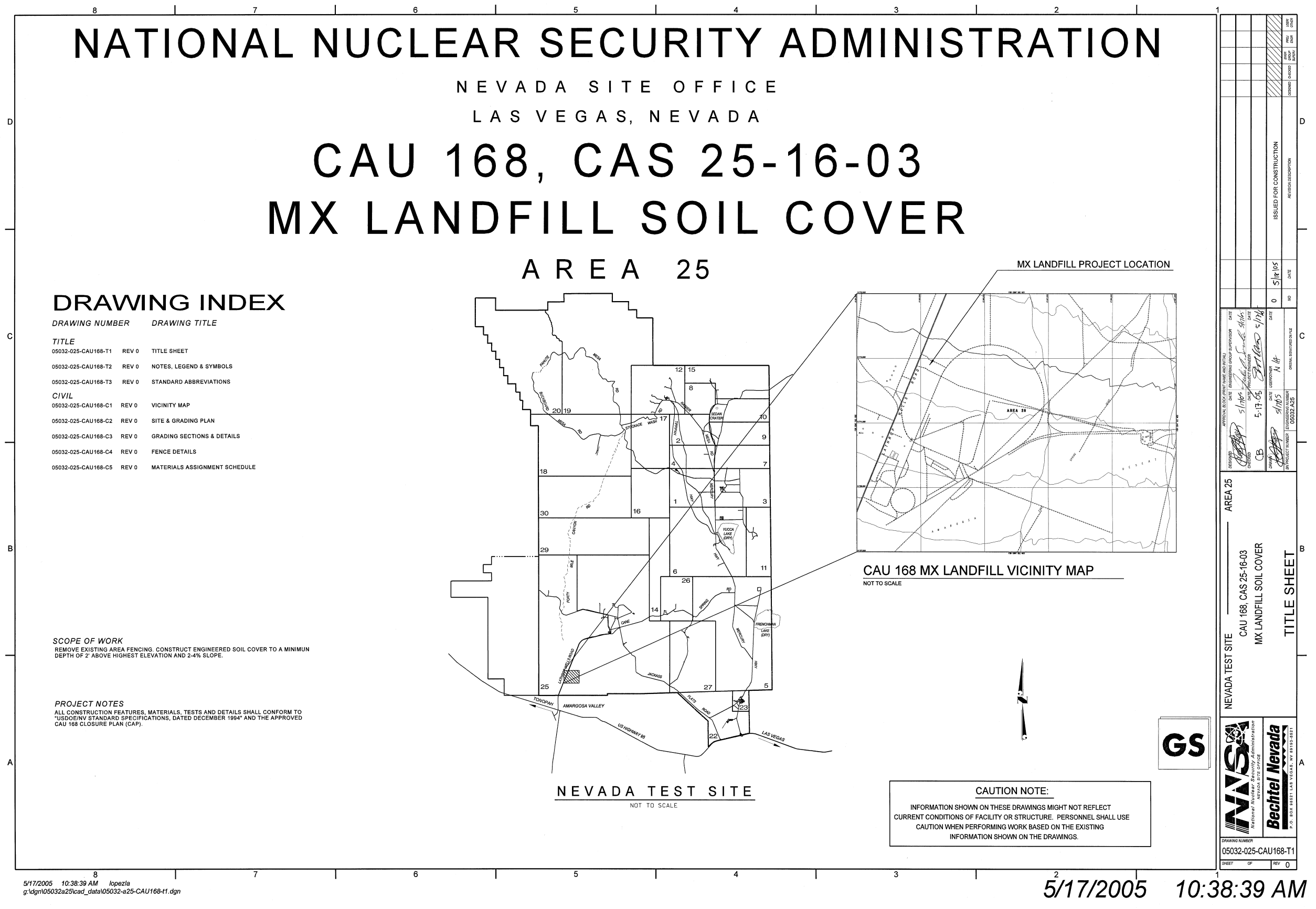




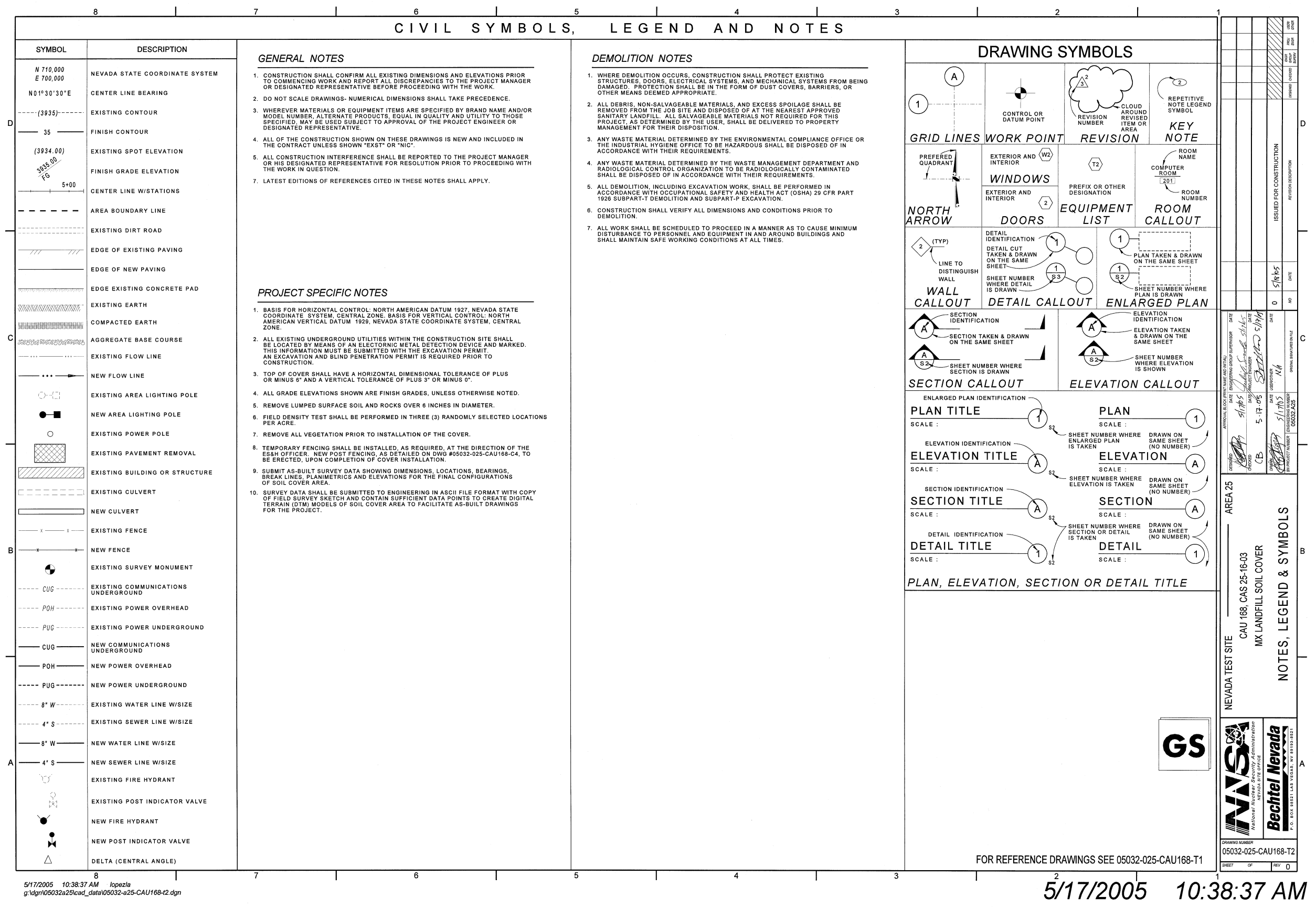




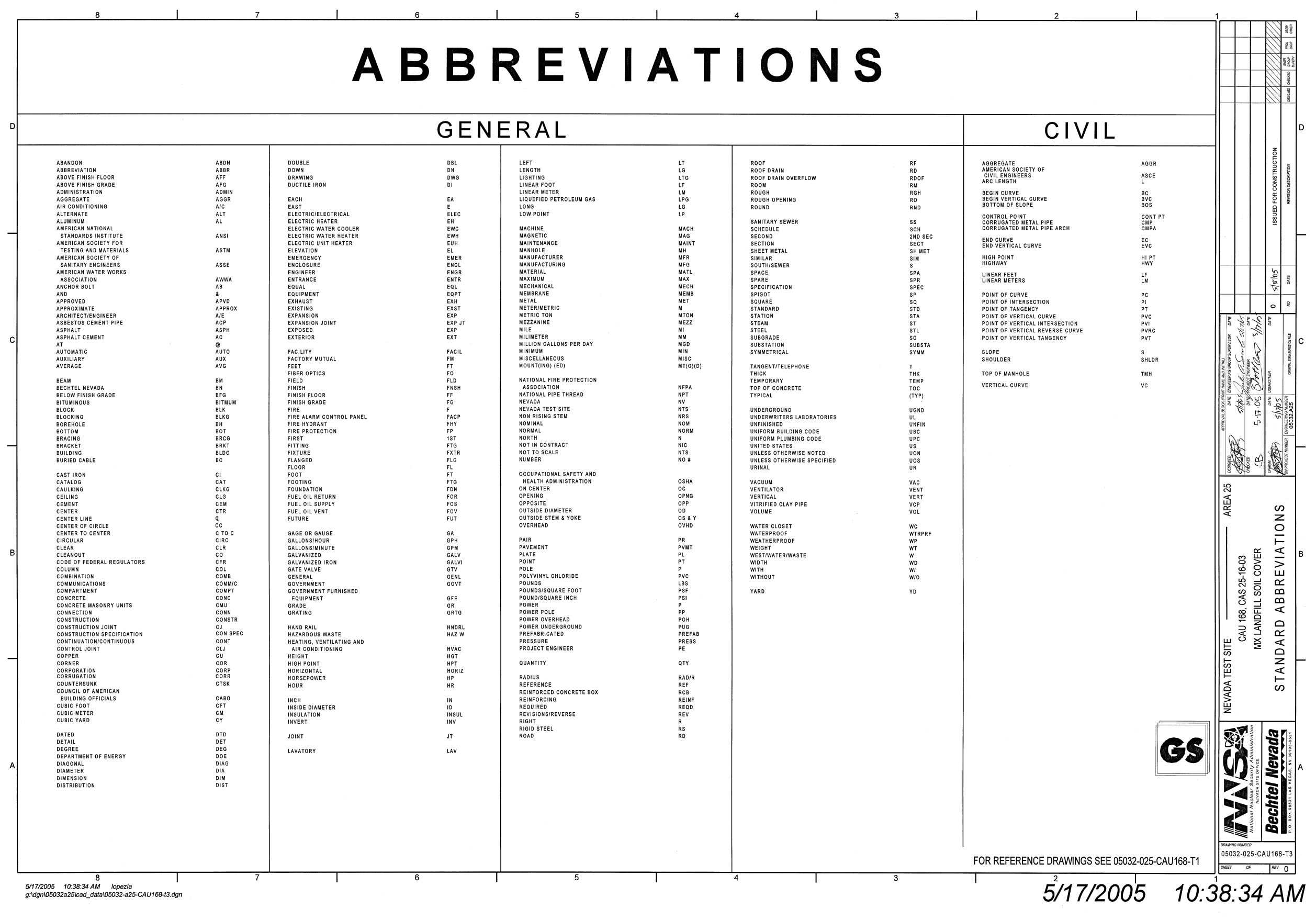




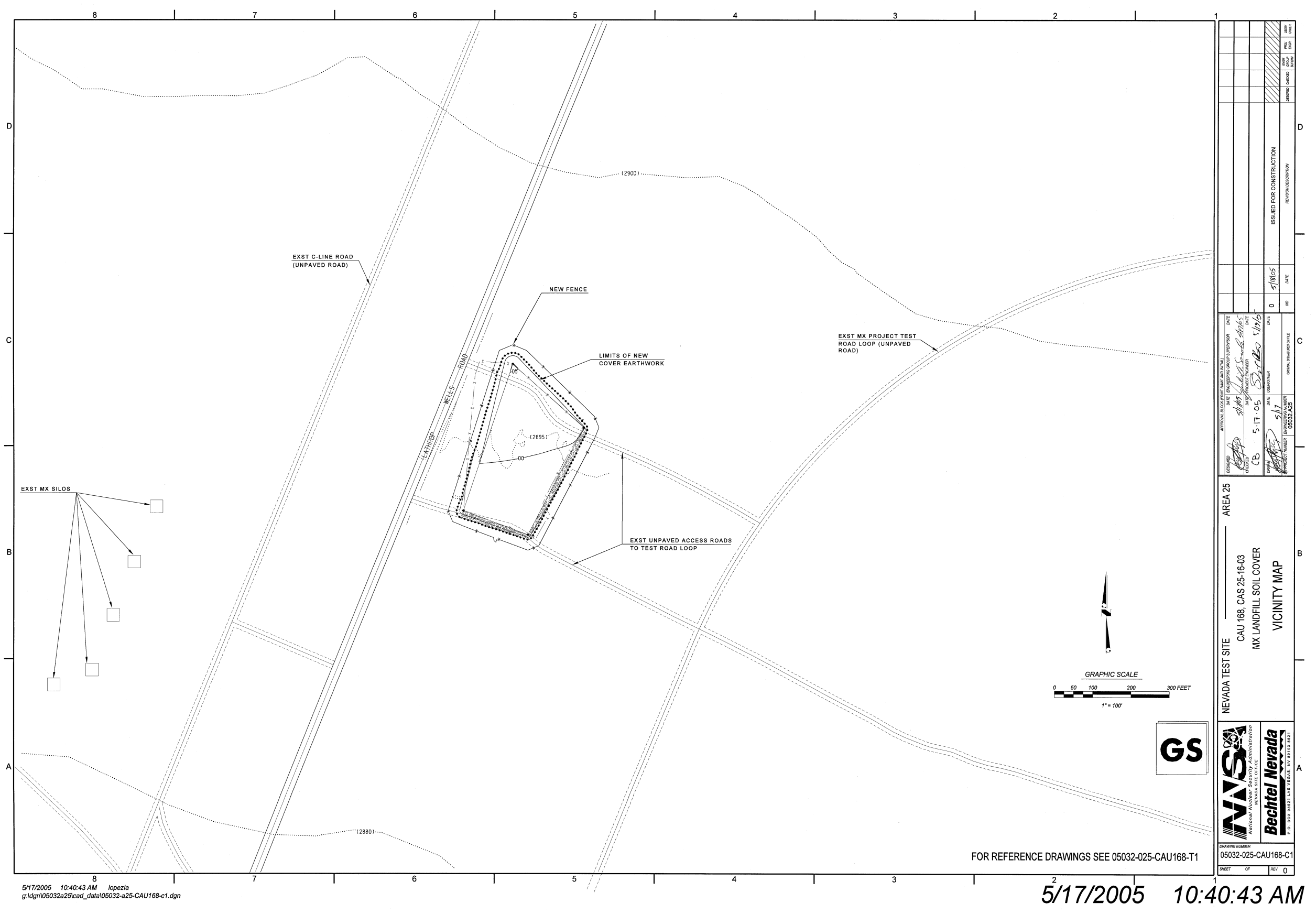




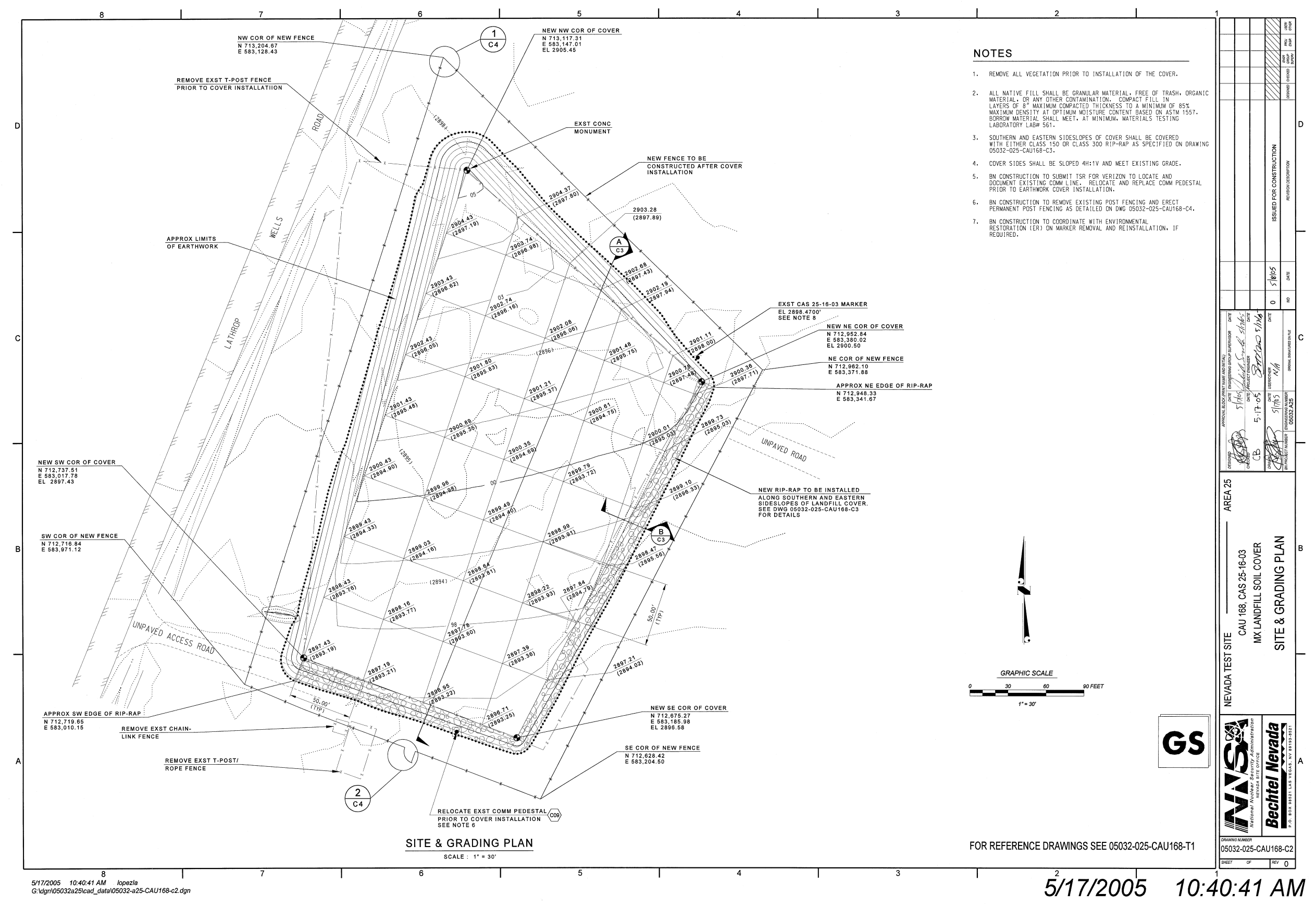




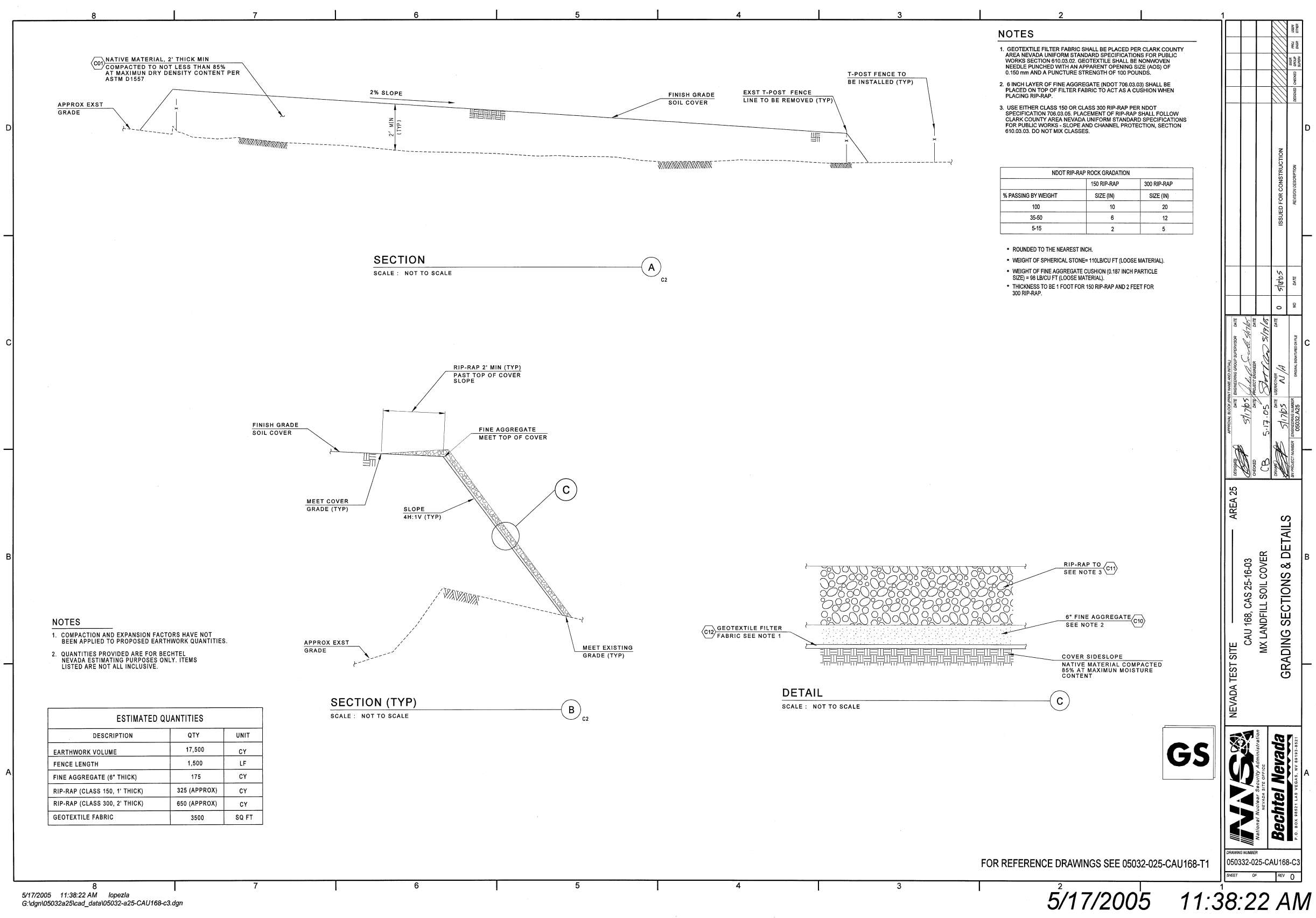




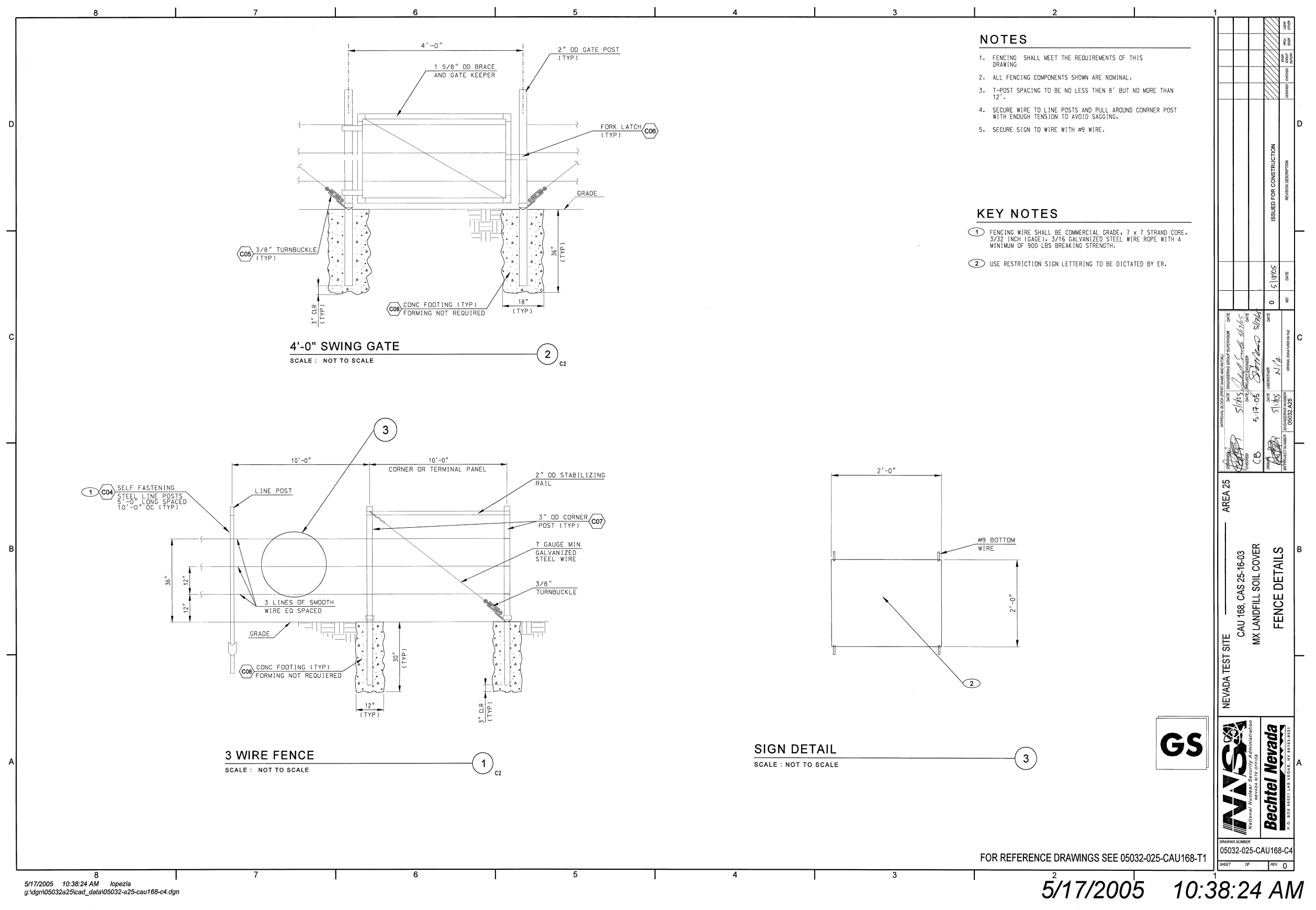




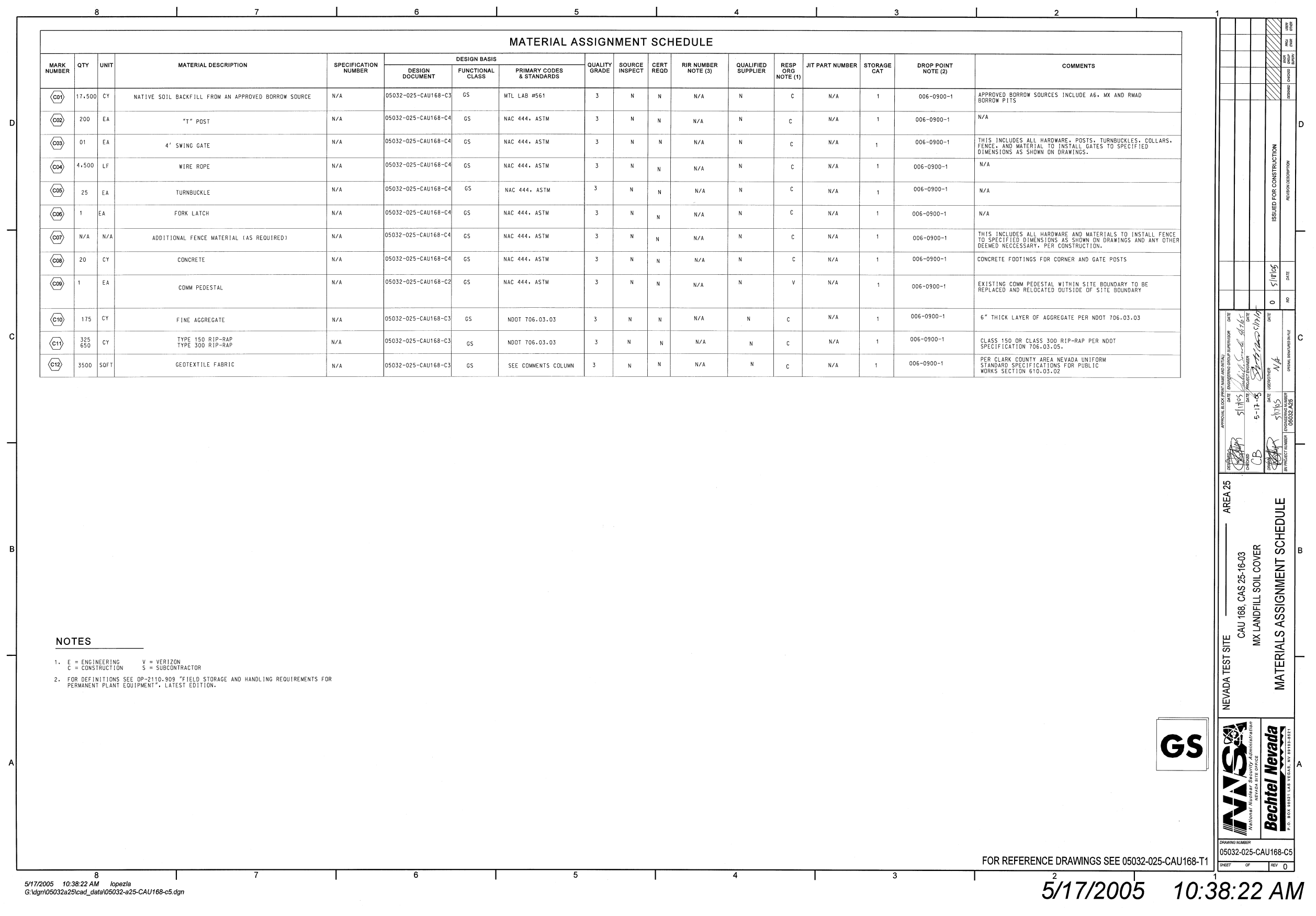




\section{APPENDIX A.2}

\section{SAMPLING AND ANALYSIS PLAN*}

*Sufficient detail on the type, number, and location of verification samples to be collected to verify site closure activities has been provided in Section 2.4.2 of this report. Waste characterization sampling activities are described in Section 2.3 of this report. This Appendix is included as a placeholder as required by the standard Federal Facility Agreement and Consent Order outline for a Corrective Action Plan. 
CAP - CAU 168

Section: Appendix A.2

Revision: 1

Date: December 2006

THIS PAGE INTENTIONALLY LEFT BLANK 
APPENDIX A.3

PROJECT ORGANIZATION 
CAP - CAU 168

Section: Appendix A.3

Revision: 1

Date: December 2006

THIS PAGE INTENTIONALLY LEFT BLANK 


\section{PROJECT ORGANIZATION}

The U.S. Department of Energy, National Nuclear Security Administration Nevada Site Office (NNSA/NSO) Federal Sub-Project Director is Kevin Cabble, and his telephone number is (702) 295-5000.

The identification of the project Health and Safety Officer and the Quality Assurance Officer can be found in both the Field Management Plan and the Site-Specific Health and Safety Plan. However, personnel are subject to change, and it is suggested that the Federal Sub-Project Director be contacted for further information. The Task Manager will be identified in the Federal Facility Agreement and Consent Order Monthly Activity Report prior to the start of field activities. 
CAP - CAU 168

Section: Appendix A.3

Revision: 1

Date: December 2006

THIS PAGE INTENTIONALLY LEFT BLANK 
CAP - CAU 168

Section: Library Distribution List

Revision: 1

Date: December 2006

\section{LIBRARY DISTRIBUTION LIST}


CAP - CAU 168

Section: Library Distribution List

Revision: 1

Date: December 2006

THIS PAGE INTENTIONALLY LEFT BLANK 


\section{LIBRARY DISTRIBUTION LIST}

U.S. Department of Energy

National Nuclear Security Administration

Nevada Site Office

Technical Library

P.O. Box 98518, M/S 505

Las Vegas, NV 89193-8518

U.S. Department of Energy

Office of Scientific and Technical Information

P.O. Box 62

Oak Ridge, TN 37831-0062

Southern Nevada Public Reading Facility

c/o Nuclear Testing Archive

P.O. Box 98521, M/S 400

Las Vegas, NV 89193-8521

Manager, Northern Nevada FFACO

Public Reading Facility

c/o Nevada State Library \& Archives

Carson City, NV 89701-4285
1 (Uncontrolled, electronic copy)

1 (Uncontrolled, electronic copy)

2 (Uncontrolled, electronic copies)

1 (Uncontrolled, electronic copy) 
CAP - CAU 168

Section: Library Distribution List

Revision: 1

Date: December 2006

THIS PAGE INTENTIONALLY LEFT BLANK 